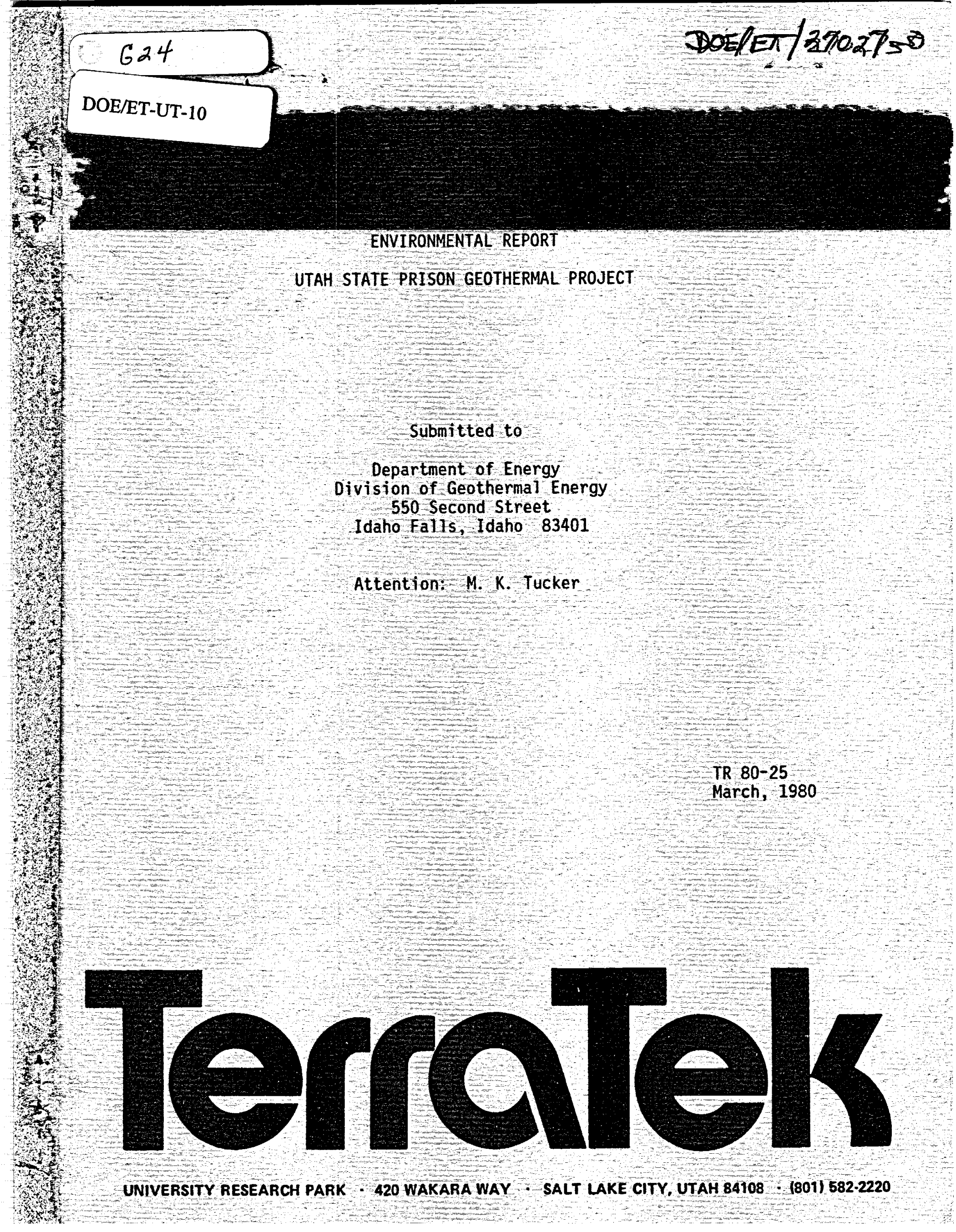




\section{DISCLAIMER}

This report was prepared as an account of work sponsored by an agency of the United States Government. Neither the United States Government nor any agency Thereof, nor any of their employees, makes any warranty, express or implied, or assumes any legal liability or responsibility for the accuracy, completeness, or usefulness of any information, apparatus, product, or process disclosed, or represents that its use would not infringe privately owned rights. Reference herein to any specific commercial product, process, or service by trade name, trademark, manufacturer, or otherwise does not necessarily constitute or imply its endorsement, recommendation, or favoring by the United States Government or any agency thereof. The views and opinions of authors expressed herein do not necessarily state or reflect those of the United States Government or any agency thereof. 


\section{DISCLAIMER}

Portions of this document may be illegible in electronic image products. Images are produced from the best available original document. 


\title{
ENVIRONMENTAL REPORT \\ UTAH STATE PRISON GEOTHERMAL PROJECT
}

\author{
Submitted to \\ Department of Energy \\ Division of Geothermal Energy \\ 550 Second Street \\ Idaho Falls, Idaho 83401 \\ Attention: M. K. Tucker \\ Submitted by \\ Terra Tek, Inc. \\ University Research Park \\ 420 Wakara Way \\ Salt Lake City, Utah 84108
}

TR 80-25

March, 1980 
Page

Contents......................... . .

List of Illustrations . . . . . . . . . . . . . . . . . iii

Acknowledgements ...................... . . iv

1. Introduction .. . . . . . . . . . . . . . . . . . . . . . . . . 1

1.1 Site Location. . . . . . . . . . . . . . . . . . . . 1

1. 2 Project Objectives . . . . . . . . . . . . . . . . . . . 1

1. 3 Participants . . . . . . . . . . . . . . . . . 3

1.4 Activity Schedule... . . . . . . . . . . . . . . 4

1.5 Costs........................ . . . . 4

2. Description of Proposed Activity . . . . . . . . . . . . . . . . 7

2.1 Resource Assessment . . . . . . . . . . . . . . . . . 7

2.1.1 Exploration .................. . . 7

2.1.2 Production Well Siting................ 9

2.2 Reservoir Development . . . . . . . . . . . . . . . . . 11

2.2.1 Drilling. . . . . . . . . . . . . . . . . . 11

2.2.2 Well Testing . . . . . . . . . . . . . . . . 11

2.3 Construction of Demonstration Facilities . . . . . . . . . 12

3. Description of Existing Environment . . . . . . . . . . . . . . 15

3. 1 Geography, Demography, and Land Use... . . . . . . . 15

3.2 Geology... . . . . . . . . . . . . . . . . . 15

3.3 Hydrology. . . . . . . . . . . . . . . . . . . 19

3.4 Seismicity . . . . . . . . . . . . . . . . . . . . 20

3.5 Soils........................ . . 20

3.6 Air Quality. . . . . . . . . . . . . . . . 21 
3.7 Meterology . . . . . . . . . . . . . . . . 21

3.8 Flora and Fauna ................. . . 21

3.9 Sensitive, Threatened, or Endangered Species . . . . . . 22

3.10 Human Environment . . . . . . . . . . . . . . . . . 22

4. Environmental Effects of Proposed Activity . . . . . . . . . 23

4.1 Land Use . . . . . . . . . . . . . . . . . . . . . . . . . 23

4.2 Geology ................. . . . . 23

4.3 Water Resources . . . . . . . . . . . . . . . 24

4.4 Air Quality ................ . . 24

4.5 Flora and Fauna . . . . . . . . . . . . . . 25

4.6 Socioeconomics . . . . . . . . . . . . . . . . . . . . . 25

4.7 Potential Accidents . . . . . . . . . . . . . . 25

5. Environmental Monitoring Programs . . . . . . . . . . . 27

6. Reclamation and Restoration.............. 27

7. Alternatives to Proposed Action . . . . . . . . . . . . 29

8. Irreversible and Irretrievable Commitments
of Resources . . . . . . . . . . . . . . . . 29

9. Trade-Off Analysis ................ . . 31

10. Compliance with Regulations and Other Controls ........ 33

References . . . . . . . . . . . . . . . 35

Appendices . . . . . . . . . . . . . . . . . . . $A 1$

A. Schedule and Cost Sharing Summary ........... A1

B. Proposed Test Drilling Program ........... . B1

C. USGS Geothermal Well Operations ............ C C1

D. Utah Division of Water Rights: Rules and
Regulations for Geothermal Wells ......... D1 


\section{LIST OF ILLUSTRATIONS}

- $\quad \underline{\text { Page }}$

- 1. Location of Utah State Prison................... . 2

;

2. Program Schedule .. . . . . . . . . . . . . . . . . . . 5

3. Utah Prison and Crystal Hot Springs. . . . . . . . . . . . . . 10

4. Schematic Flow Chart of Proposed Demonstration. . . . . . . . . . . . . . . . . . . . 13

5. Known and Inferred Structure in Vicinity of Crystal Hot Springs . . . . . . . . . . . . . . . . . 16

6. Aerial Photo of the Utah State Prison . . . . . . . . . . . . . . 17 


\section{ACKNOWLEDGEMENTS}

Terra Tek wishes to acknowledge the assistance of $\mathrm{Mr}$. Peter Murphy (Utah Geological and Mineral Survey), Mr. D. H. Crockett (Private Consultant) and Mr. Jeff Burks (Utah Energy Office) in the preparation of the report. In addition we are indebted to Mr. Peter Murphy for providing a draft copy of his report on Crystal Hot Springs and to $\mathrm{Mr}$. D. H. Crockett for doing most of the "leg work" for this report. 


\section{INTRODUCTION}

This environmental report assesses the potential impact of developing a geothermal resource for space heating at the Utah State Prison. Wells will be drilled on prison property for production and for injection to minimize reservoir depletion and provide for convenient disposal of cooled fluid. The most significant environmental concerns are the proper handling of drilling muds during well drilling and the disposal of produced water during well testing. These problems will be handled by following currently accepted practices to reduce the potential risks.

\subsection{Site Location}

The proposed project will be developed at the Utah State Prison about 15 miles south of Salt Lake City (Figure 1). It is located near the towns of Draper, Riverton, and Bluffdale in the southeastern part of the Jordan Valley (also known as the Salt Lake Valley). Crystal Hot Springs are the surface evidence of the thermal resource and they are located less than $1000 \mathrm{ft}$. from the major building complex.

\subsection{Project Objectives}

The objective of the project is to demonstrate the use of geothermal energy for direct utilization at the Utah State Prison. The Crystal Hot Springs geothermal resource will be developed to provide space and hot water heating for the Prison's Minimum Security Block. The immediate objectives to be met during the course of this project are:

- To assess the energy potential of the Crystal Hot Springs and demonstrate its suitability for exploitation in direct heat applications. 


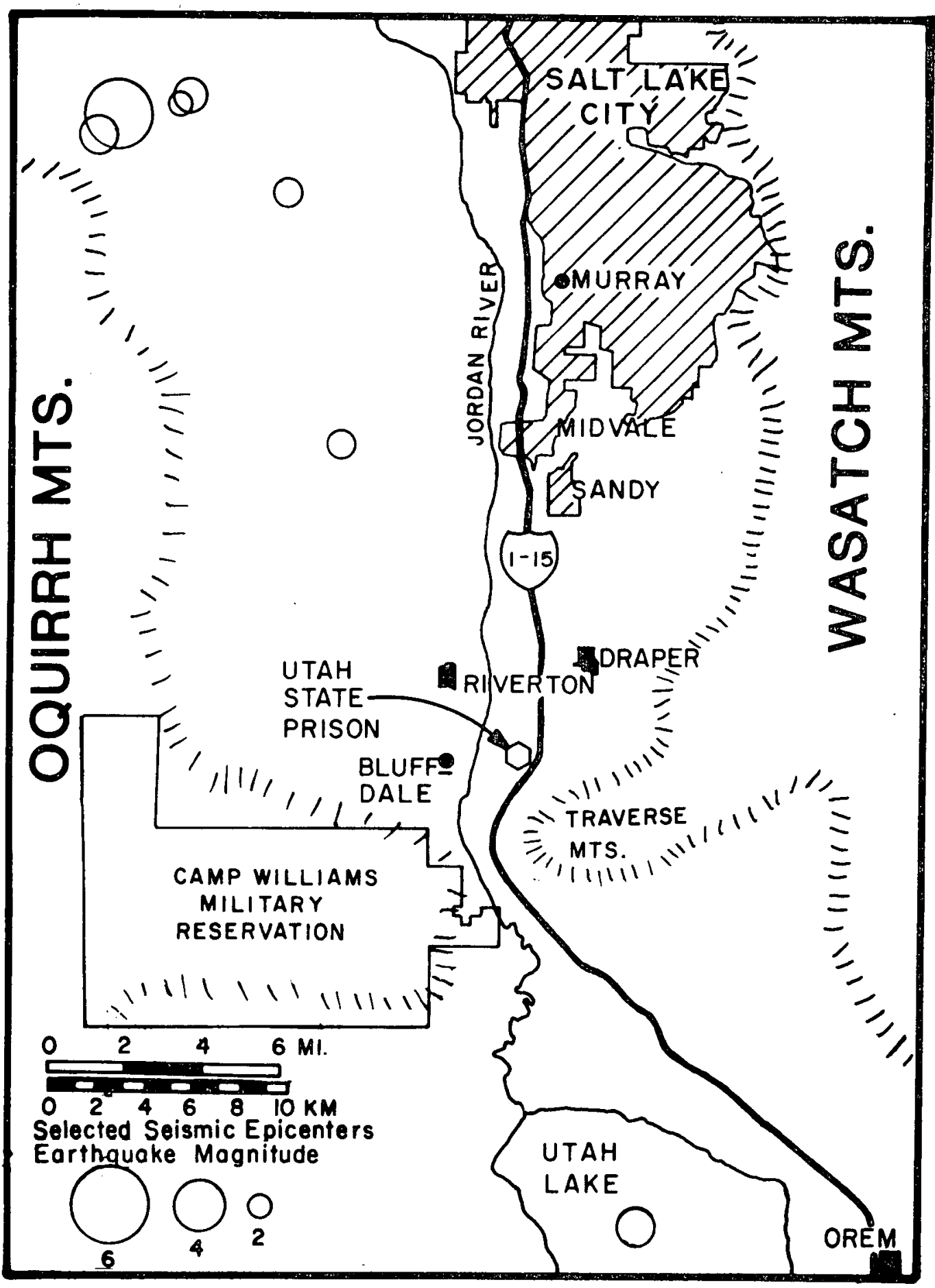

Figure 1. Location of Utah State Prison. Selected seismic epicenters of magnitude > 2 that occurred between July, 1962, and September, 1978. (From Arabasz et a1., 1979). 
- To demonstrate the viability of integrating the necessary geothermal hardware with existing heating systems.

- To demonstrate the potential for expansion of the initial development throughout the prison complex and to other possible commercial developments such as an industrial park in the area as well as the greenhouse complex planned by Utah Roses, Inc.

- To assess the long term benefits and define opportunities created by development of the geothermal resource.

- To establish a state fund for financial support of geothermal direct heat applications which will provide incentives for similar demonstrations at the state level.

- To identify and address the regulatory and economic constraints with the assistance of appropriate state agencies in order to accelerate the development of low temperature geothermal resources within Utah.

\title{
1. 3 Participants
}

Overall activities will be managed by the Program Director in the Utah Energy Office, State of Utah. Program Management will be in the Utah Department of Social Services and the Utah State Building Board. Terra Tek, Inc. will be Technical Coordinator and the Utah Geological and Mineral Survey will be responsible for resource assessment. The U. S. Department of Energy and their contractor, EG\&G Idaho, Inc., will provide technical assistance. The primary individuals responsible and the agencies they represent are as follows:

\author{
Mr. Jack Lyman - Director, \\ Utah Energy Office \\ Mr. Chuck Davies - Program Manager, \\ Utah Department of Social Services
}




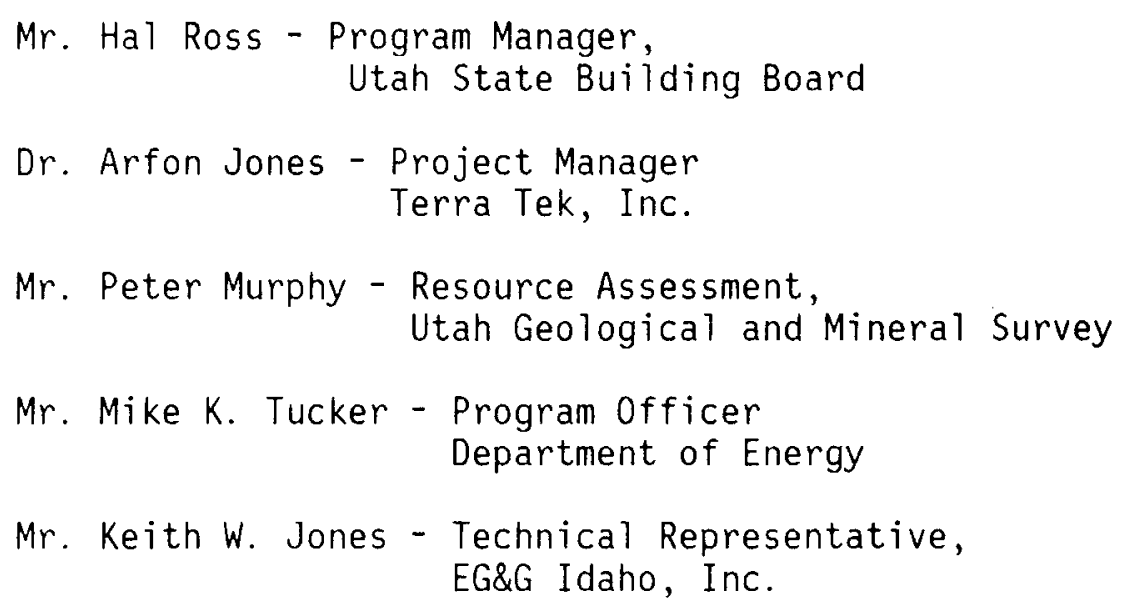

\subsection{Activity Schedule}

Development of the Crystal Hot Springs geothermal resource will occur in three phases:

- Phase I - Resource Assessment

- Phase II - Field Development

- Phase III - Construction and Inspection of Demonstration

The anticipated work schedule is shown in Figure 2.

\subsection{Costs}

The total estimated cost for the project is $\$ 637,326$. Shared costs for the State of Utah and DOE are shown below. Appendix $A$ is a complete cost sharing summary.

Total Estimated Costs Utah State Cost Share

DOE Share
$\$ 637,326$

$(178,622)$

$\$ 458,704$ 


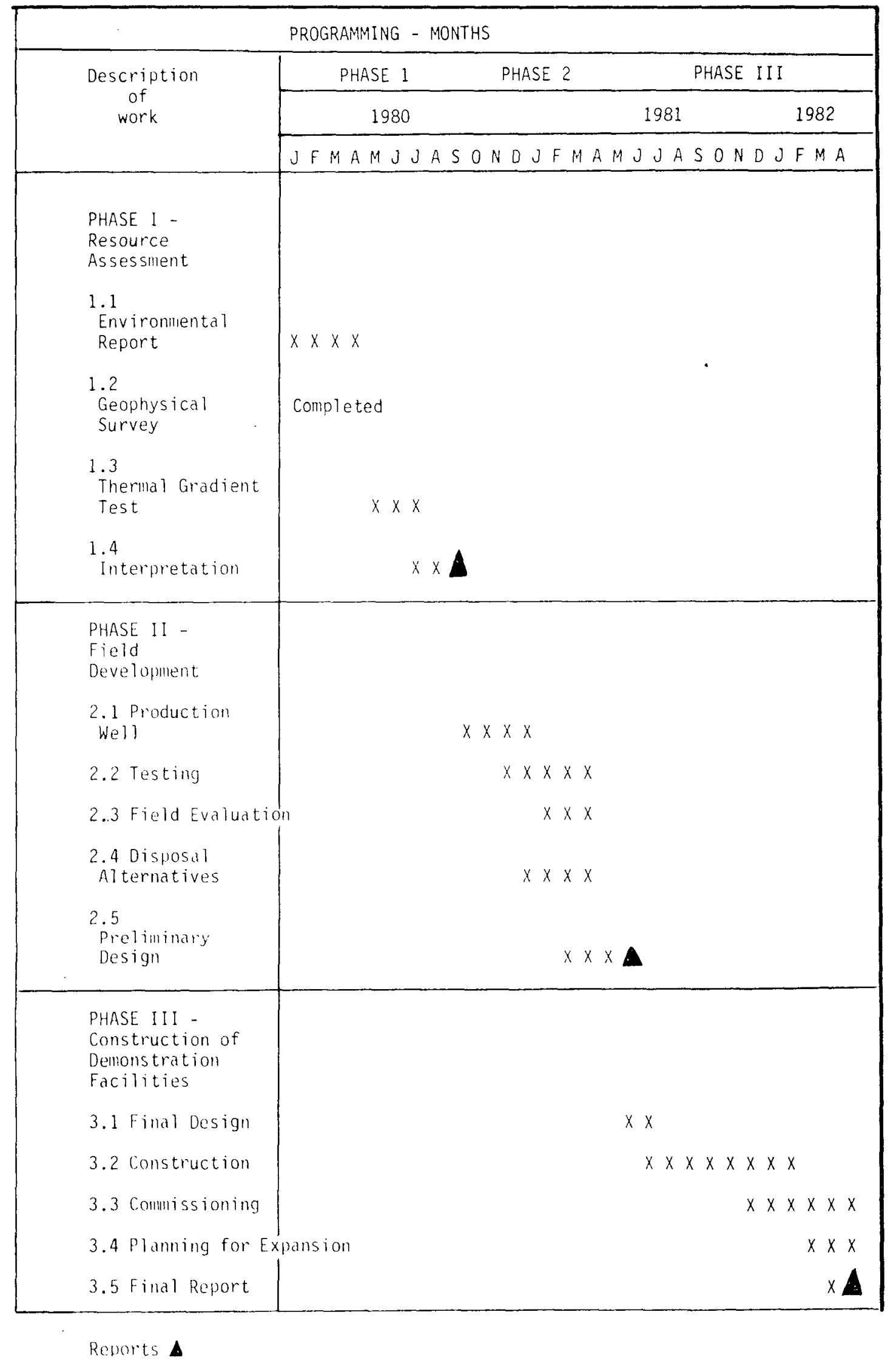

Figure 2. Program Schedule 


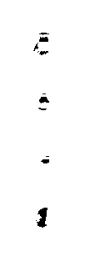

$=$

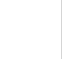

. 


\section{DESCRIPTION OF PROPOSED ACTIVITY}

The tasks to be carried out as part of each phase of the program are as follows:

Phase 1 Resource Assessment

- Additional geophysical reconnaissance of Crystal Hot Springs.

- Identification of production drilling site.

Phase 2 Field Development

- Driliing and testing of production well.

- Evaluation of well and reservoir.

- Preliminary system design and optimization

Phase 3 Construction of Demonstration Facilities

- Final system design.

- System installation.

- Commissioning and initiation of plant monitoring program.

- Development of plan for expansion of the demonstration.

\subsection{Resource Assessment}

\subsubsection{Exploration}

A preliminary assessment of the Crystal Hot Springs area has been conducted by the Utah Geological and Mineral Survey (UGMS) as part of their Department of Energy (DOE) funded program (state coupled) to document and assess the low temperature geothermal resources in the State of Utah. The initial investigation included: literature search, general reconnaissance, aerial mapping, a vertical field magnetometer survey, a thermal gradient survey in existing water wells, and a shallow ground temperature survey. In addition, six thermal gradient well were drilled to further define the extent 
of the resource and provide data on the geology, hydrology and near surface thermal conditions of the reservoir.

A more detailed resource assessment was undertaken by UGMS beginning in October, 1979, under the terms of a Cooperative Agreement with the Utah Energy Office and the DOE State Coupled Program. This consisted of the following geophysical surveys:

1. Detailed gravity grid. A $3000^{\prime} \times 5000^{\prime}$ area centered on the Crystal Hot Springs and the prison compound. A total of 290 stations were occupied on a 350-foot grid.

2. Gravity profiles. These gravity profiles covered an area along the front of the Traverse range (on the apron of the mountain) from Camp Williams to Draper with $1000^{\prime}$ spacings along each profile. A total of 257 stations were occupied.

3. Aeromagnetic Survey. This survey was flown $500 \mathrm{ft}$. above ground level with $1 / 8$ mile between flight lines that were oriented northsouth. The northern limit was approximately Sandy city and the southern limit was an east-west line through Camp Williams.

The detailed gravity grid (Item 1 above) was financed under the State Prison PON. Gravity profiles and the aeromagnetic survey were funded under the UGMS-DOE/DGE State Coupled program.

Results of the geophysical surveys have recently been obtained from the subcontractor and are being interpreted by UGMS with assistance from the University of Utah Earth Science Laboratory. Interpreted geophysical results will be used to site a test hole (referred to below as USP/TH-1). 


\subsubsection{Production well siting}

To provide better information for siting of the production well, a test drilling program will be conducted as proposed by UGMS (Appendix B). This will involve two wells: 1) Deepening an existing well known as SF-1 (State Forestry well in Figure 3) to a depth of 500 feet, and 2) Drilling a new test hole, USP/TH-1, to a depth of approximately 1,000 feet. The most likely area for this well is also shown in Figure 3.

USP/TH-1 will be drilled at the preferred location for the production well so that it can be completed as the production well if sufficient hot water is available. This test hole, and a separate production hole to be drilled only if necessary, will be sited on the basis of all existing resource data including:

1. Results of all UGMS-DOE/DGE State Coupled Program investigations.

2. PON financed geophysical and test hole drilling programs.

3. Results of non-DOE/DGE related drilling and testing (as available).

Site selection will also be influenced by non-resource parameters such as 1) accessibility (property boundaries and land usage both existing and anticipated); and 2) the economics of piping. Master plans developed for the modernization of prison facilities may preclude the siting of the wells in certain locations that are presently accessible. Piping costs can be minimized with the production well near the Minimum Security Building. 







\subsection{Reservoir Development}

\subsubsection{Drilling}

Reservoir development will proceed by drilling and completing a production well with a design capacity of $600 \mathrm{gpm}$. The we 11 will be drilled to a target depth of $1000 \mathrm{ft}$ and cased to the top of the production zone, probably within several hundred feet of the bottom of the hole. Drilling will be done on pre-existing sites or sites prepared by the state of Utah. It will be supervised by a Terra Tek engineer who will be on-site at all times during drilling operations. This individual will represent the interests of the Prison Space Heating Project.

It is anticipated that water will be used as a drilling fluid. If water is inappropriate and the drilling fluid is used, the fluid will be stored in portable tanks or mud pits. Blowout procedures will be followed as prescribed by the USGS and the Utah Division of Water Rights regarding geothermal wells (see Appendices $C$ and $D$ ).

\subsubsection{Well Testing}

Upon completion of the production well, a testing program is scheduled to confirm the long-term deliverability of the well. The following operations will be conducted:

1. Initial flow Tests. A steady production flow rate will be maintained using an airlift pump. The enthalpy of the discharge and pressure drawdown at the production zone will be monitored until steady-state is reached. In addition, interference with the Utah Roses well, surrounding test and thermal gradient wells and the hot springs will be monitored. The State of Utah allows surface discharge during well testing.

2. Production Test. The discharge enthalpy and drawdown will be determined over a range of stable production conditions. 
3. Chemical Sampling. The chemistry of the well discharge and natural springs will be monitored throughout the test program and any changes noted.

4. Assessment. The test results will be reviewed in conjunction with the resource assessment data. Estimates will be made of the reservoir yield which can be sustained under production and the expected resource life. These estimates will form the data base for detailed design of the distribution and heat exchange equipment.

5. Materials Testing. Testing of the corrosive and sealing nature of the geothermal fluid will be initiated. This will provide the base data necessary for materials selection.

\subsection{Construction of Demonstration Facilities}

The demonstration project will focus on the Minimum Security Building as the most promising candidate for conversion to geothermal heat. In the present system, heat supplied from the central boiler plant is exchanged to fresh water which is circulated through the building. Retrofit will entail adding geothermal water/fresh water heat exchangers in series with the present steam/water units for both space and culinary water heating. Apart from the addition of some supplementary pumping capacity, the rest of the existing system can be left essentially intact.

A schematic flow chart of the proposed demonstration is shown in Figure 4. The storage tank and heat exchangers will be located near Minimum Security's heating plant. Fiberglass reinforced pipe will be used to transport geothermal water between the wells and heat exchangers. The production piping will be insulated with approximately two inches of polyurethane which will be protected with a PVC outer wrapping. The pipe will be laid along the ground surface. 




Figure 4. Schematic Flow Chart of Proposed Demonstration 
To provide for long-term water disposal during operation of the demonstration facility, the cooled water will be injected into the permeable sands and gravels which provide subsurface drainage from the hot springs area. For this purpose, the ASARCO well shown in Figure 3 may be used or an injection well will be drilled on prison property north of the building complex. This location is down the hydraulic gradient and therefore the injected water will be assimilated into the general groundwater flow northward away from the hot springs.

A full scale commissioning program will be undertaken at the completion of the installation phase. Standard operating and safety procedures will be determined by simulating failures in sensitive equipment (e.g., pipes, pumps, control valves, etc.). Many of the operating procedures will be determined by the plant behavior during this commissioning stage. For example, some equipment will be sensitive to thermal and mechanical shock loading (heat exchangers, downhole pump, piping). Rigid procedures will be specified for plant warm-up and cooling. A systematic maintenance program will be developed based on the individual equipment requirements. Maintenance schedules will be designed to coincide with periods of low-load demand in order to minimize periods of plant shutdown.

The Prison maintenance staff will keep a comprehensive record of the geothermal field and plant performance noting flow rates, pressures, temperatures, equipment failures and down-time. This will provide the data base for an accurate study of the engineering reliability of the system. In addition, an annual well test and field sampling program will be initiated to monitor trends in the field characteristics and provide data for extrapolation of field performance with present and for future development. 


\section{DESCRIPTION OF EXISTING ENVIRONMENT}

\subsection{Geography, Demography, and Land Use}

The location of the Utah State Prison is shown in Figure $I$ in relation to Salt Lake City, Draper, Riverton, Bluffdale, and the surrounding mountains. It is adjacent to the Traverse Mountains which form the southern boundary of the Jordan Valley between the Wasatch Mountains to the east and the Oquirrh Mountains on the west. Figure 5 shows the prison property in relation to Bluffdale and the Traverse Mountains. Figure 6 is an aerial photo of the area.

From the mid-1800's to the $1930^{\prime} \mathrm{s}$ the valley was largely agricultural with irrigated crops of alfalfa, small grains, corn, and sugar beets and for pasture. The population of the area has increased rapidiy from the 1950's to the present. Marginal farming, sand and gravel operations, and a meat processing plant compose the business activities in the southern part of the valley. New residential encroachment is occuring east of I-15 near Draper and south of Sandy and Riverton (Figure 1).

\subsection{Geology}

The Jordan Valley is an alluvium filled graben along the eastern edge of the Basin and Range physiographic province. The valley is bounded on the east by the Wasatch Fault and the Wasatch Mountains, on the west by the Oquirrh Mountains, and on the south by the Traverse Mountains. The Wasatch Mountains consist of Precambrian and Paleozoic sedimentary units that were intruded by the Little Cottonwood stock during late Tertiary time. The stock is a quartz monzonite intrusive about 7 miles across and located east of Draper and Sandy. 


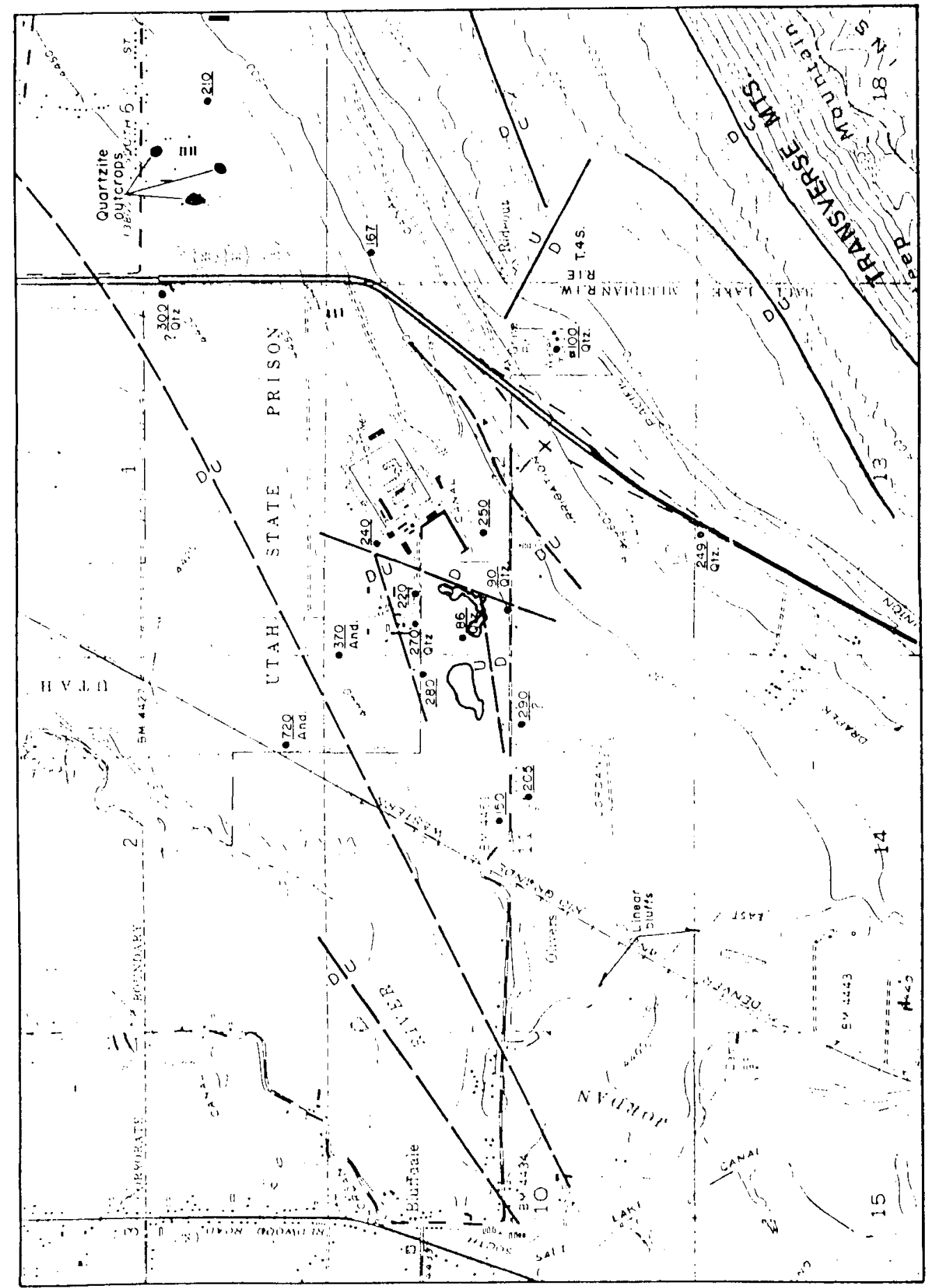

Figure 5. Known and Inferred Structure in Vicinity of Crystal Springs (From Murphy and Gwynn, 1979) 


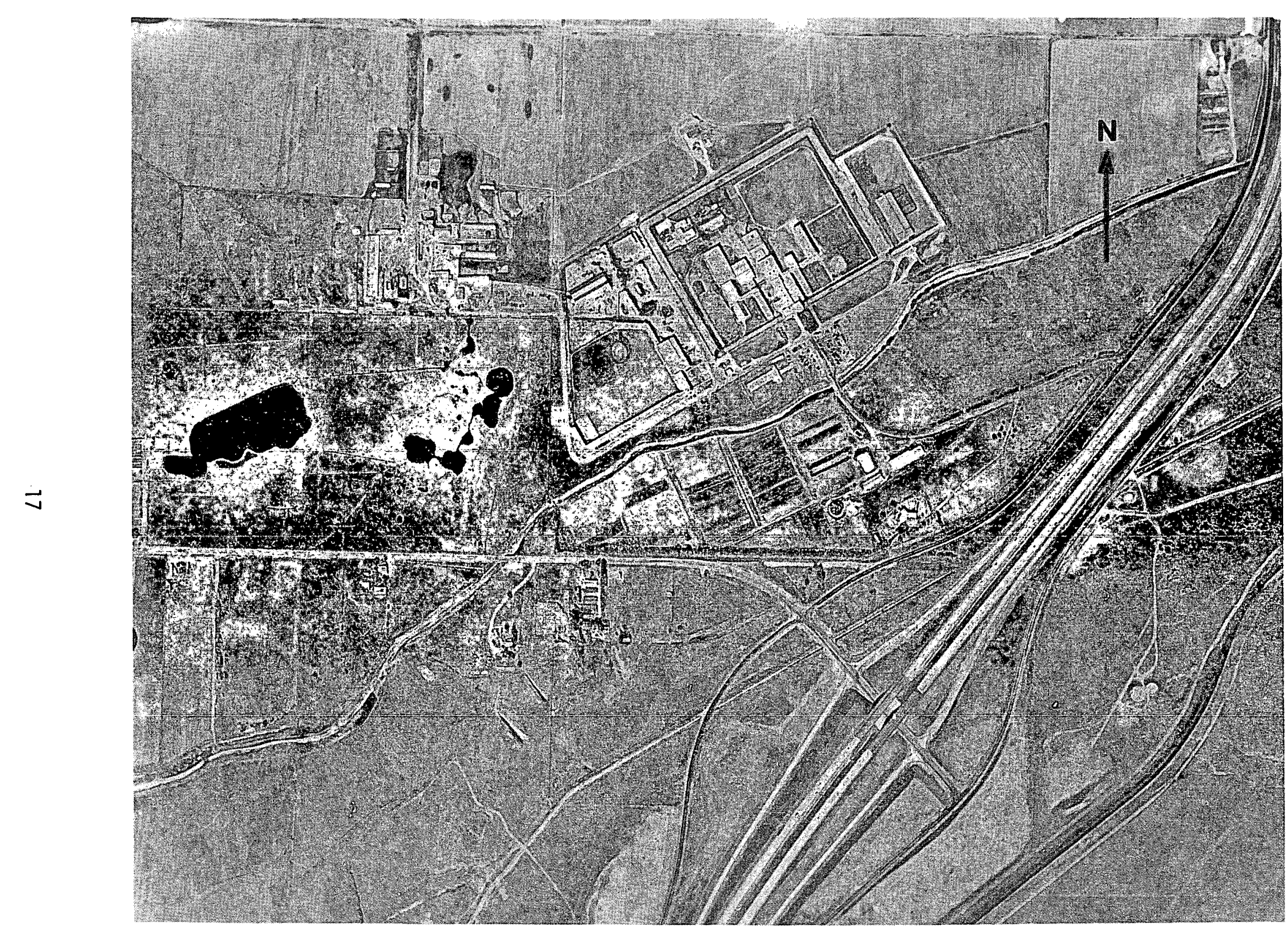

Figure 6. Aerial Photo of the Utah State Prison. 
The Oquirrh Mountains consists of the folded and fractured Oquirrh formation composed of quartzites and limestones of Pennsylvanian age. Tertiary volcanics, primarily andesitic lava flows, mantle some sections of the Oquirrh Mountains.

The Traverse Mountains have been described as a horst separating the Jordan Valley graben to the north and the Utah Valley graben to the south, and are divided into east and west ranges by a graben in the Jordan Narrows (Pitcher, 1957). The range consists primarily of the Oquirrh formation and is overlain in places by Tertiary volcanics deposited on the eroded surface of the Oquirrh formation. The volcanics are andesitic flows that are quite variable in thickness and much more extensive on the western side of the range than in the east. Most of the rocks of the Traverse Mountains are intensely fractured as noted by geologists who have mapped the area (Marshe11, 1932; Pitcher, 1957; Bullock, 1958).

The structure of the crystal Hot Springs area is complex because the Traverse Mountains trend east-west in a region where the prevailing structural trends are north-south. Murphy and Gwynn (1979) have discussed three structural trends in the area (northeast, north-northeast, and northwest) and the influence they have in controlling the location of the geothermal resource. Figure 5 shows the known and inferred structures in the vicinity. The most prominent fracture set is a series of normal range front faults that strike northeast and dip northwest toward the Jordan Valley graben. The second set of fractures strike north-northeast, a trend first noticed at the eastern edge of the spring system. The third set of structures trends northwest and is expressed by a fault in the Rideout quarry that displaces the Provo shoreline fault (Murphy and Gwynn, 1979). The northeast trending faults appear to limit 
the expression of the geothermal resource and may actually define the limits of the system at depth.

\subsection{Hydrology}

The surface expression of the geothermal resource is restricted to an area of about 70 acres bounded by the prison farm to the north, the minimum security buildings to the east, the Bluffdale road to the south and several farms to the west (Figure 3 ). No surface manifestations of the thermal system have been found outside of this area.

The spring system includes a large western lake and smaller ponds and orifices east of it. The springs flow at approximately $100 \mathrm{gpm}$ and have a maximum surface temperature of $80^{\circ} \mathrm{C}$. The water has a total dissolved solids content of 1,100 to $1,700 \mathrm{ppm}$. Typical chemistry of the water is given in the table below:

CHEMICAL COMPOSITION OF CRYSTAL HOT SPRINGS
$\begin{array}{lc}\text { (From Utah Energy } & \text { Office, 1978) } \\ \text { pH } & 7.6 \\ \text { Silica } & 60 \mathrm{ppm} \\ \text { Calcium } & 100 \\ \text { Magnesium } & 25 \\ \text { Sodium } & 300 \\ \text { Bicarbonate } & 280 \\ \text { Sulphate } & 100 \\ \text { Chioride } & 600 \\ \text { TDS } & 1500\end{array}$


The Jordan River which drains Utah Lake flows northward about $1 / 2$ mile of Crystal Hot Springs (Figure 5). The East Jordan Canal, transporting irrigation water diverted from the Jordan River, flows northeast past the hot springs and across prison property. Based on the regional hydraulic gradient, the ground water flow in the area is north-northwest from the Traverse Mountains toward the Jordan River.

\subsection{Seismicity}

The Intermountain Seismic Belt is a 60 mile wide zone of relatively high seismicity extending from northern Arizona to northwestern Montana and locally coincident with the Wasatch Front (Murphy and Gwynn, 1979). The University of Utah Seismograph station has plotted the epicenters of events which were of magnitude $\geq 2.0$, within 30 miles of the project site, and occurred between July, 1962, and September, 1978. The largest, of magnitude $=5.2$, occurred on September 5, 1962, at Heber City, 25 miles to the east. Those earthquakes which have occurred within the area are shown in Figure 1 (Arabasz et al., 1979).

\subsection{Soils}

The soils in the vicinity of the Crystal Hot Springs consist of silty clay loam in river bottom land adjacent to the Jordan River and loams occurring on the gently sloping terrace land deposited along the ancient shorelines of Lake Bonneville (Soil Conservation Service, 1974). This latter soil is part of the Provo Formation formed as the result of lateral mixing of lacustrine materials such as silts and clays with an overwash of flood and sheetwash materials such as sands and gravels. Surface soils are dominated by silt-loam and loam and are nearly level throughout the area of the proposed activities. 


\subsection{Air Quality}

Those industries which impact air quality are located either north of the project area within the immediate vicinity of Salt Lake City, or south, near Orem and Provo. As noted previously, almost no heavy industry is present in the southern part of the valley. Occasional temperature inversions and stagnant air prompt the National Weather Service to issue air quality warnings for the area.

\subsection{Meteorology}

The climate of the Jordan Valley is dry subhumid with an average annual precipitation of 12 inches and average annual temperature of $10^{\circ} \mathrm{C}$. Summers are generally hot and dry, and the relative humidity averges between 20 and 30 percent during summer afternoons (Soil Conservation Service, 1974). Winters are cold but extended periods of severe cold are rare. Precipitation is relatively light during summer and early fall and reaches a maximum in spring. The wettest month is usually April and the driest one is July. Winds are generally light to moderate during all seasons, but strong damaging winds occasionally occur (Soil Conservations Service, 1974). The orographic effects of the Wasatch Mountains causes the average annual precipitation to be 30 inches at the higher elevations with a maximum of 50 inches at some ski resorts.

\subsection{Flora and Fauna}

The native vegetation on the lake plains near the Jordan River includes saltgrass, meadow grasses and sedges, and quackgrass. Small herbivorous rodents are the predominant mammals in the area. 


\subsection{Sensitive, Threatened, or Endangered Species}

There are no known threatened or endangered species within the project area.

\section{10 Human Environment}

The area surrounding the Utah State Prison for a two-mile radius is largely rural with an occasional grouping of two or more dwellings. Some single new homes are being constructed nearby but there are no large scale subdivisions. The primary sources of income are from employment in local manufacturing, the Bingham Canyon mine and the copper smelter at Magna, and two large electronic assembly plants within 6 miles which manufacture calculators and digital watches. A small percentage of the population commutes the 15 miles into Salt Lake City. The only recognized Historical Site nearby is a marker located $2000 \mathrm{ft}$ south of the prison fence which commemorates the Rockwell's stagecoach station. 


\section{ENVIRONMENTAL EFFECTS OF PROPOSED ACTIVITY}

\subsection{Land Use}

The drilling and development will occur entirely on Utah State Prison property and will be integrated into Phase I of the prison masterplan for new construction and rehabilitation of existing facilities. Direct use of land will be approximately 1 acre for the two well sites and the pipelines from the wells to the Minimum Security Building. Since the proposed development is small compared to existing facilities and will be integrated with construction plans by the prison staff, the aesthetic quality of the area will not be diminished.

\subsection{Geology}

Temporary disruption of surface soil will occur during drilling of the wells and laying the pipelines. The surface impact is considered small compared to other prison construction activities that will be carried out concurrently with the geothermal development. With proper excavation, these short term effects to the prison's environment will be minimal and integrated into the existing landscape.

Although earthquakes have been triggered by injecting very large volumes of water into seismically active areas, there have been no known occurances directly attributable to producing or injecting at a geothermal site. It is not expected that the wells at the prison would affect seismic activity because of small volumes of water and the small faults bounding the hydrothermal resource. Should an increase in seismic activity occur following development, surveys will be initiated to monitor such activity.

Surface subsidence can occur when large quantities of water are withdrawn 
from unconsolidated sediments. However, the proposed reservoir development involves small water volumes and includes injecting cooled water back into the sediments. Therefore, detectable surface subsidence is not anticipated.

\subsection{Water Resources}

The only environmental concern of significance that is related to this project is the impact to surface water and groundwater during drilling and testing of the wells. Orilling mud will be contained in mud pits or portable mud tanks. Drilling muds contain a high percentage of clay and silt that will inhibit the seepage of poor quality fluids into shallow ground-water systems.

During testing of the production well, but before the injection well has been drilled, produced water will have to be disposed on the surface. Fortunately, the quality of water from the Crystal Hot Springs and produced water from the Utah Roses well is good. It should be feasible to discharge water into the East Jordan Canal or the drainage channel from the hot springs for short periods of time during well testing and until the complete system is installed and operating.

Since the demonstration project is designed as a closed roop (i.e. ininjecting cooled water back into the hydrological system), there should be no impact on surface water. The State of Utah has non-degradation regulations which are in effect with respect to injection into the ground water system. From the data presently available, the quality of the geothermal water is as good as the quality of water in the injection horizons. Therefore, no longterm detrimental effects to the ground water system are anticipated.

\section{4 Air Quality}

Sources of air pollution from this project are only short-term ones and include dust from cleared areas, vehicle emmissions during drilling, and 
release of dissolved gases in the geothermal fluids (Lance, 1978). Dust can be controlled to a great extent by graveling or watering cleared areas. The only troublesome dissolved gas emitted from geothermal fluids is hydrogen sulfide and emissions will occur only during testing of the well when surface disposal is required.

\subsection{Flora and Fauna}

The impact to flora and fauna results from clearing of land for roads, drill sites and piping facilities. These activities will occur on prison property and will require only minimal removal of vegetation or displacement of fauna. The area anticipated for drilling and laying the pipelines is practically void of vegetation and wildilfe.

\subsection{Socioeconomics}

Drilling the wells and installing the geothermal water/fresh water heat exchangers will have no long term adverse impact on housing, utilities, or services. In fact, some benefits are expected since the presence of a geothermal demonstration facility will stimulate an energy consciousness. There are no archeological sites within the project area which will be affected by the proposed activity.

\subsection{Potential Accidents}

Drilling procedures will be in accordance with acceptable drilling standards for geothermal wells. Blowout preventers will be installed during drilling and will remain in place until the wellhead equipment is installed upon completion of the well. Some potential for industrial accidents always exists around heavy equipment and this risk will be minimized by implementation of OSHA safety procedures and regulations. 


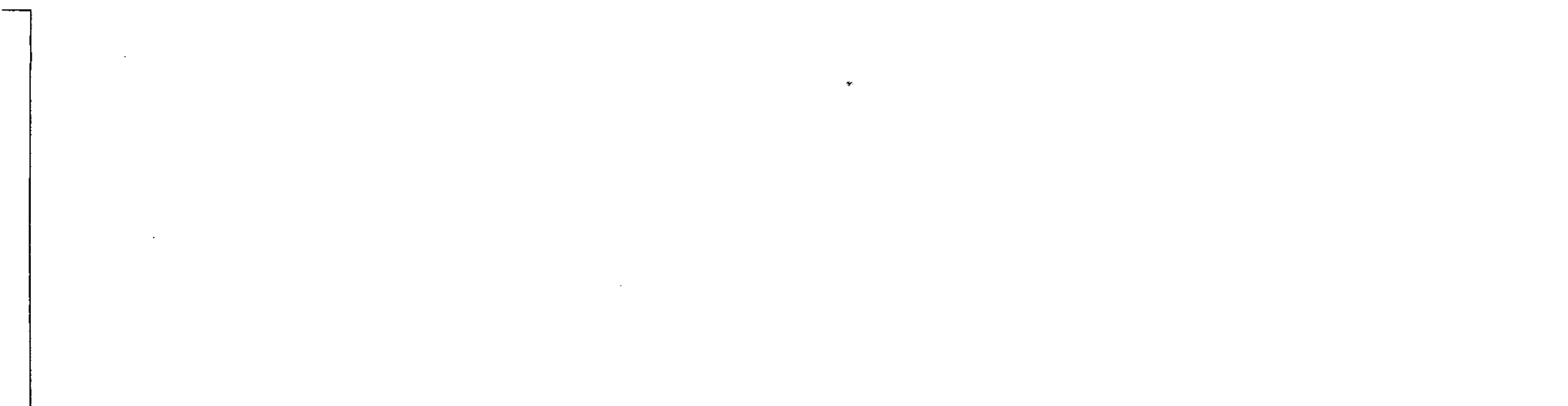

$\vdots$
$\cdot$
$=$



$\because$

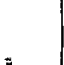

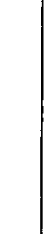




\section{ENVIRONMENTAL MONITORING PROGRAMS}

The planned monitoring program will concentrate on surface water and ground water since these are the only significant factors of environmental concern. The response of the shallow wells and surface springs will be recorded during the periods of well testing. Samples from the production well and the springs will be taken periodically throughout the course of the project and analyzed for TDS, major chemical constituents, and $\mathrm{pH}$.

\section{RECLAMATION AND RESTORATION}

The contractor and the State of Utah will conduct the project in such a manner as to minimize erosion and disturbance of the natural drainage. This will be accomplished by providing structures that will prevent excessive runoff and subsequent erosion at the site of the production well and the land within the main compound area. Water, drilling fluids, petroleum or other material that may have a deleterious effect on the soil and plants will be contained and disposed of in the appropriate manner. Measures will be taken to mitigate or lessen any damage during construction, especially during and after the laying of the pipelines for the distribution system. The State of Utah shall impose those standards it normally would use during similar construction where streets, roadways, gutters, and other improvements are disrupted or damaged. 


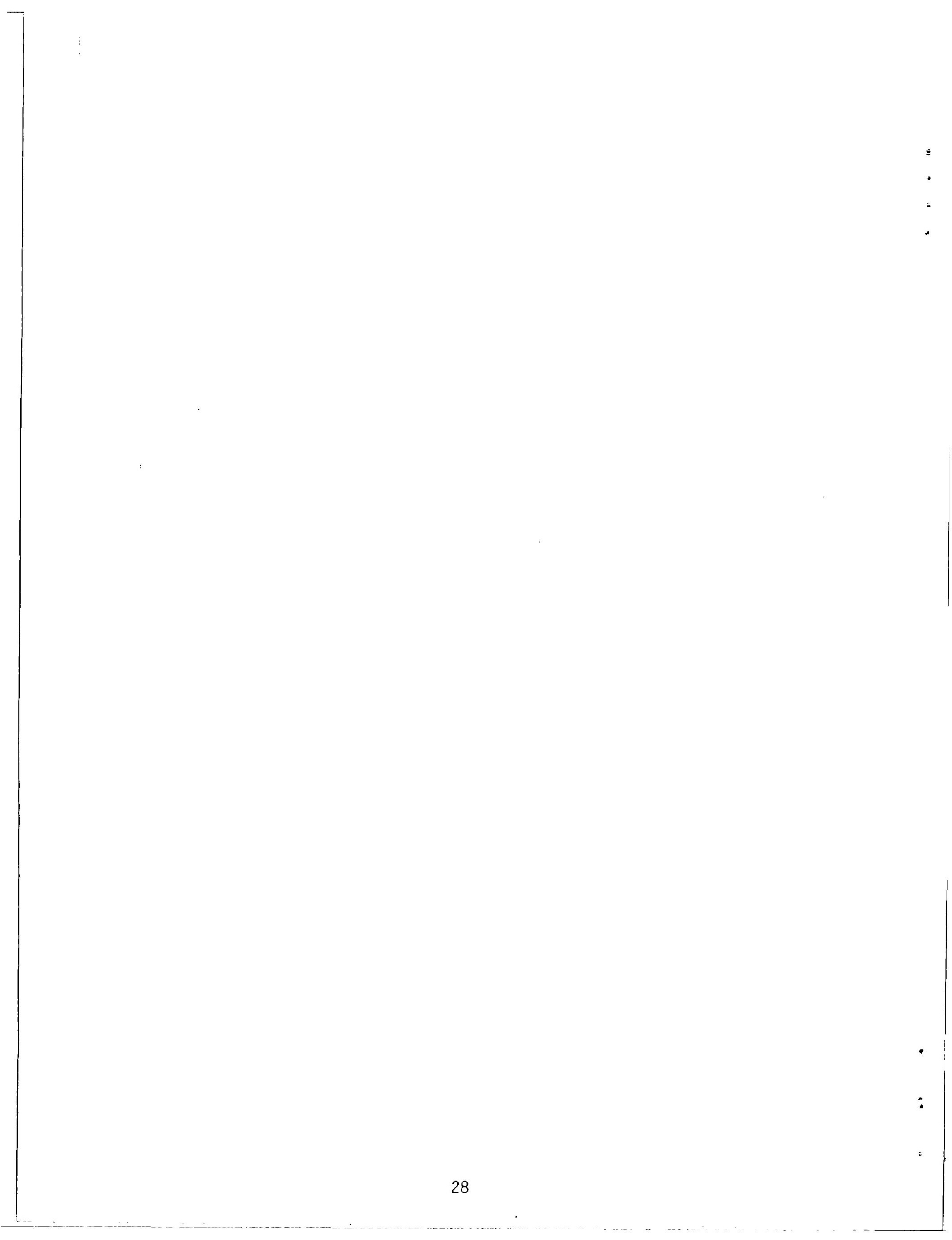




\section{ALTERNATIVES TO PROPOSED ACTION}

The alternatives available within the scope of the proposed activity pertain to the location of the production well and the disposal of the water after it is discharged from the heat exchangers. As stated previously, the area within which the production well will be located is shown in Figure 3. The merit of having the well closer to the Minimum Security Building is the lower cost of transmission pipe. This factor will be compared with the requirement of placing the well in a location for maximum productivity. This decision will be made after the test drilling program has been completed.

The alternatives for water disposal include using an injection well as discussed in this environmental report or discharge into the presently existing channel which drains water from Crystal Hot Springs. The injection well option is considered to have less environmental impact. The State of Utah has non-degradation regulations and therefore the water will be injected deeper than the few (5-7) residential wells within a mile of the site. There are no irrigation wells in the area to be affected since irrigation water is obtained from the East Jordan Canal. The impact of discharging into the existing channel would be minimal since it already drains hot water from Crystal Hot Springs.

\section{IRREVERSIBLE AND IRRETRIEVABLE COMMITMENTS OF RESOURCES}

The commitment of resouces is the financial investment in drilling and completing the wells, installing the piping, and retrofitting the heating systems in the Minimum Security Building. 


\section{TRADE-OFF ANALYSIS}

At present, the Utah State Prison consumes an estimated 120 million cubic feet per year of natural gas, the least expensive and environmentally clean fuel for the Salt Lake area in recent years. Rapidly rising gas costs provide the motivation to develop geothermal resources and thereby conserve non-renewable natural gas. Failure to develop Crystal Hot Springs means losing the opportunity to develop this non-fossil fuel energy source.

The expected cash savings is the projected natural gas not required by the Minimum Security less the operating and maintenance expenses incurred because of the system. Assuming a system life-cycle of thirty years, a summary of discounted savings at a ten percent required rate of return is as follows (Utah Energy Office, 1978):

$\begin{array}{ccc} & \text { ESTIMATED AVERAGE } & \text { DISCOUNTED } \\ \text { YEARS } & \text { NET SAVINGS/YEAR } & \\ & & \\ 1-10 & \$ 23,500 & \$ 140,000 \\ 11-20 & 32,900 & 76,000 \\ 21-30 & 45,700 & 42,000 \\ & & \end{array}$

$\$ 258,000$

The use of coal as an energy source for the prison cannot be seriously considered. Transportation costs for coal are higher than for gas and environmental problems of burning coal are much greater. Wind power also cannot be seriously considered because the winds which occur are not strong or for sustained periods of time. Besides, wind power is used to produce mechanical energy rather than heat energy. 


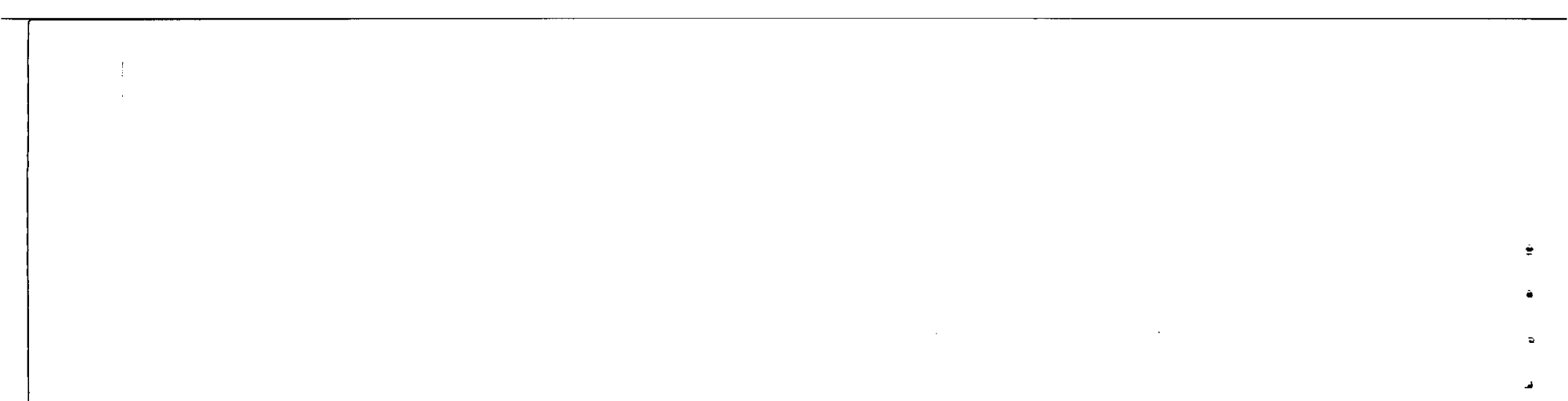




\section{COMPLIANCE WITH REGULATIONS AND OTHER CONTROLS}

All Salt Lake County Zoning and Planning Regulations are invoked. All permits pertinent to the development of the geothermal resource have been or will be obtained. As provided in Utah State Code (annotated), Section 73-1-20, the Division of Water Rights (State Engineer) has prepared Drilling Regulations for Geothermal Wells and all drilling activities will comply with these regulations. Notice of intent to drill has been filed with the State Engineer's Office and approved. Copies of the State regulations regarding drilling of wells and the well drilling regulations are included in Appendices $C$ and $D$. 


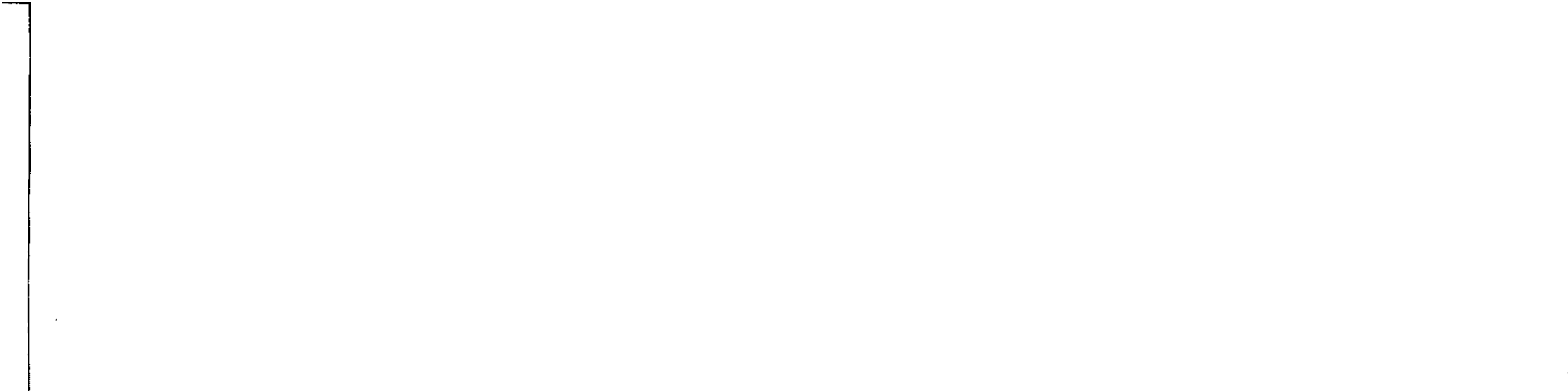

.

.

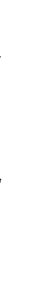

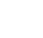

.

:

.

. .

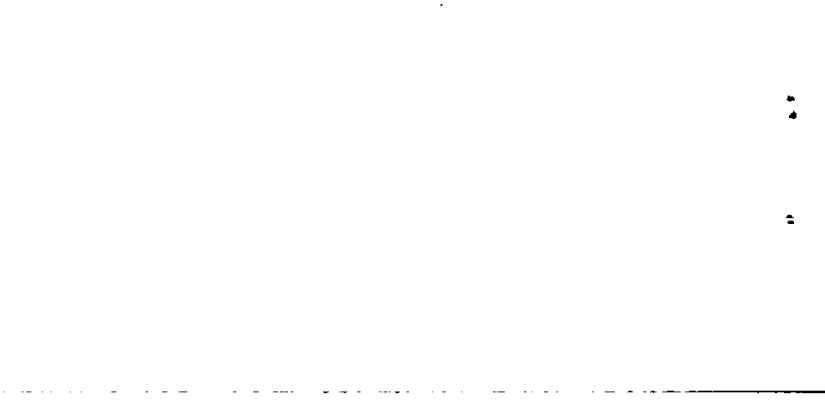




\section{REFERENCES}

Arabasz, W. J., R. B. Smith and W. D. Richins (editors) (1979). Earthquake Studies in Utah 1850 to 1978; University of Utah Seismograph Stations, Department of Geology and Geophysics, University of Utah.

Bullock, R. L. (1958). The Geology of Lehi Quadrangle; M.S. Thesis, Brigham Young University.

Lance and Associates (1978). Environmental Report: Green River Greenhouse Geothermal Project.

Marse11, R. E. (1932). Geology of the Jordan Narrows Region, Traverse Mountains, Utah; M.S. thesis, University of Utah.

Murphy, P. J. and J. W. Gwynn (1979). Geothermal Investigations at Crystal Hot Springs, Salt Lake County, Utah; Utah Geological and Mineral Survey, Report of Investigation No. 139.

Pitcher, G. G. (1957). The Geology of the Jordan Narrows; M.S. thesis, Brigham Young University.

Soil Conservation Service (1974). Soil Survey of Salt Lake Area, Utah; U.S. Department of Agriculture.

Utah Energy Office (1978). Proposal for Direct Utilization of Geothermal Resources, Field Experiment at the Utah State Prison. 
Appendix A: Schedule and Cost Sharing Summary 


\section{SCHEDULE AUH COSI SHARING SIMWMRY}

couparative hatement ids.

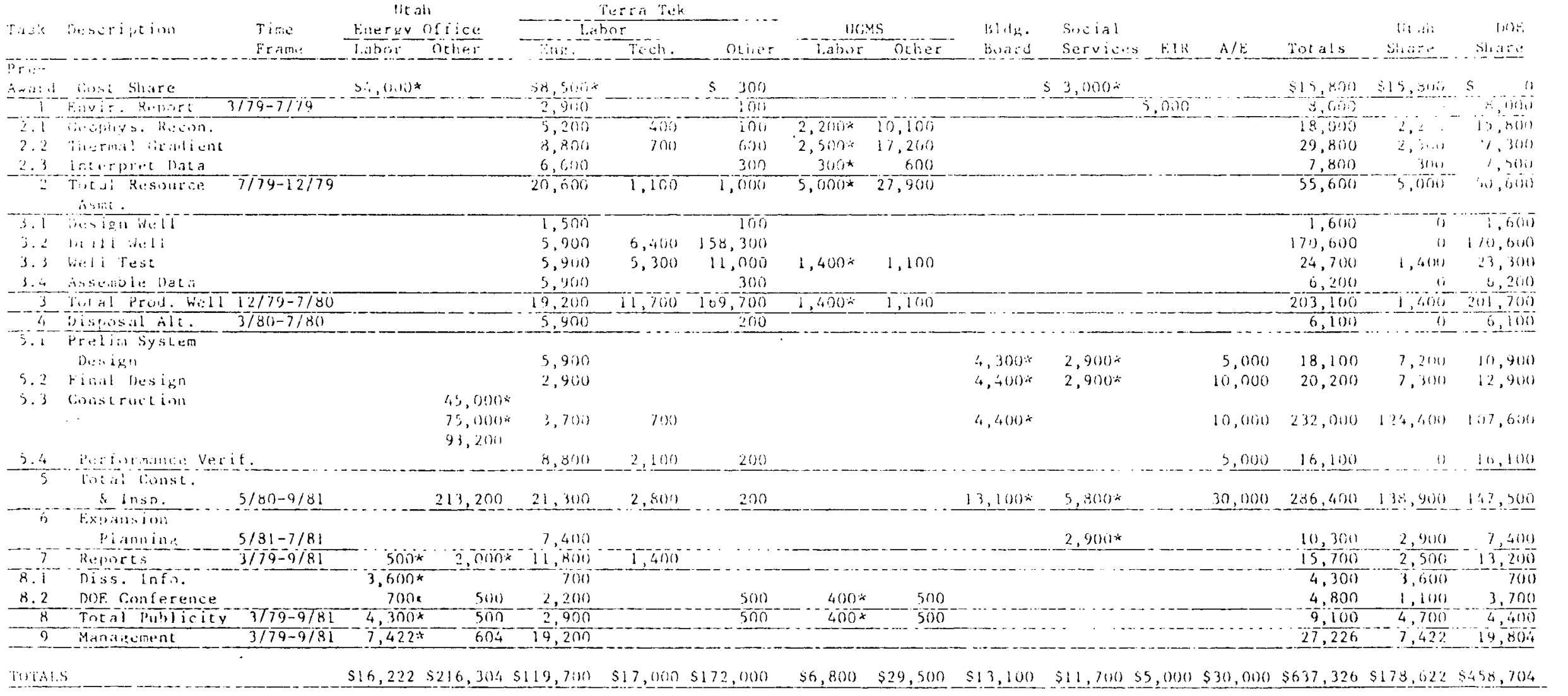



.

$=$

.

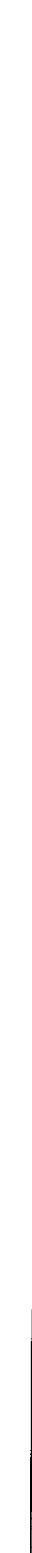

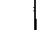

$:$

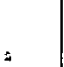


Appendix B: Proposed Test Drilling Program 




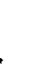
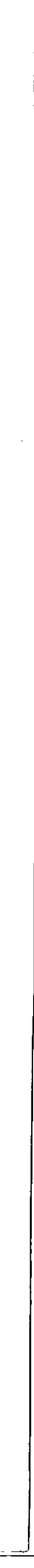
Proposed Geotiumal Test Driling Program for

the Utah state prison lield Demonstration project Near Draper, utah

\section{TNIRODUCTION}

As part of the utah state prison field demonstration project (Department of Energy/Division of Geothermal Encrgy PON) at the prison facilities in praper, utah, a test drilling program is scheduled to be conducted in June, 1980. The test drilling program will be conducted for the state of utah by UG.is under consulting agreement 806006 betwcen UCMS and the Utah Energy Office (uro). Funds for the drilling program are available through the contract (1):-FCO-79EJ27027) betwcon DOF/DGE and the UR:O.

THEST DRTILINC PROGRAM

The objective of the test dri]ling program will be to test formations and/or subsurface structures, accessible from state owned land, for the presence of thermal water. The program will consist of two parts: 1) Deepening an existing well known as SF-1. (see attached map) to a depth of 500 feet, and 2) Drilling a new test hole, USp/TH-1 (sco attached map), to a depth of 1000-1200 foet. USP/rll-l will be arilled at a site judged to be the best site for a production hole. The decision where to site USP/lH-l will be based on all available goophysical, geologic, and thermal datia including the rosults of drilling in SF-1. Should USP/TH-1 oncounter sufficiont thermal water to mort the needs of the domonstration project, thon the hole may, at a later date, be on harged and modified to act as a production hole. 
State Forestry No. 1

brilled in npril of 1978 by the state Forester's office, State lorestry No. I (SP-1) was inteided for use as a source of hot water for a small greenhouse operation. SP-l was completed by drilling a hole slightly lasger than 6 inches in diameter to a tolal depth of 280 feet. A 6 inch dialleter casing sloted in the bottom 110 feet was installed aftor ariling was completed. 'I'. aasing was grouted at the surface. A valve on the casing controls an artesian flow of approximately 12 gph. Several months ater the hole was completed, water bogan to leak around the casing at the rate of sevoral gpm, but the flow coased after approximately 6 hionths. Since being dribla, the hole has boen unused except for a puinp test conducted in Novonber of 1978. In August of 1978, fisc/laho falds ran natural gama radiation and temperature loys in the hole.

Under the purposed test drilling promam, sk-1 will be deepsned to approximately 500 foet at the maximum diameter vossible theough the 6 inch casing. Drilling will be done with water, no cosing will be placed in the deepened hole, and completion will consist of closing the valve at the well head. The temporary loahage of water around tho outside of the casing is vicwed as an indication that a good scar between the caring may not have exister. 'fluduh time, clays in the hole may have expanded to improve this soal and stop the leakage. However, in order to be assured of a beter soat at the surlace, a hole a minimu of 5 feet deep will be teavated anomi the casing and f: Hod with coment bofore di.ilima is byjun. 
USP/TH-1

Drilling and Completion

1. An 8 inch diameter hole will be drilled to a depth of 80 feet and an 8 inch casing will bo driven behind the bit. This casing will serve as conductor casing, and a valve will be installed on the casing to control any possible artesian flow. Sufficient quantities of clay should be present in the upper 80 feet (determined by gradient hole dxilling in 1978) to form an effective seal around the casing.

2. From a depth of 80 feet to the total depth of the hole, a 6 inch hole will be drilled with either water or mud (as conditions wargant). During drilling the following conditions will be closely monitored:
a) condition of the ground surrounding the surface casing
b) circulation fiuid temperature
c) lose or gain of circulation fluid
d) drilling rate
e) 1 ithology
At any time, should changes in one or several of these parameters inaicate that:
a) the seal around the surface casing is failing, or
b) the surface casing may not control flow from the hole under changing conditons

the following actions will be taken:

1) Drilling will be haulted

2) Flow from the hole will be controlled with mud and the 6 inch bit with be removed from the hole.

3) The 8 inch diameter surface casing will be removed from the hole. 
4) The top 40 foot of hole will be cnlarged to a diameter of 12 inches.

5) An 8 inch combutor casing will be installed and grouted into place.

6) An 8 inch valve will be mounted on the casing.

7) Drilling of the 6 inch hole will continue to the desired depth.

Upon reaching the desired depth, several completion options will be considered:

1. Should the hole warrant further investigation as a production hole, and:

a) roquire no adational casing to maintain the hole, then the inole will be closed by the valve.

b) reguire additional casing to maintain the hole, then a three inch casing will be run into the hole and the valve: closed.

2. Should the hole be judged of no further value to the cxploration orogram, then:

a) 2 inch casing slotted at the bottom will be run into the hole to a desirea level.

b) the slotted scotion will bo gravel packed.

c) the romainder of the anulus between the hole and the casing will bo back filled with the cutting then grouted from 100 fect to the surface.

d) Clow from tho two inch pine, if any, will be controlled by a value.

Completed in this manner, the hole will be useful as an observation weil for testing of a future production hole. 
When abandoned, the 2 inch casing will be filled with grout. If either option la or $l b$ is chosen, and cvaluation of the hole indicates that it can be used as a production hole, then the hole may be enlarged. Division of Water Rights will be kept informed of the options being considered, and will be consulted before any additional work is undertaken. 


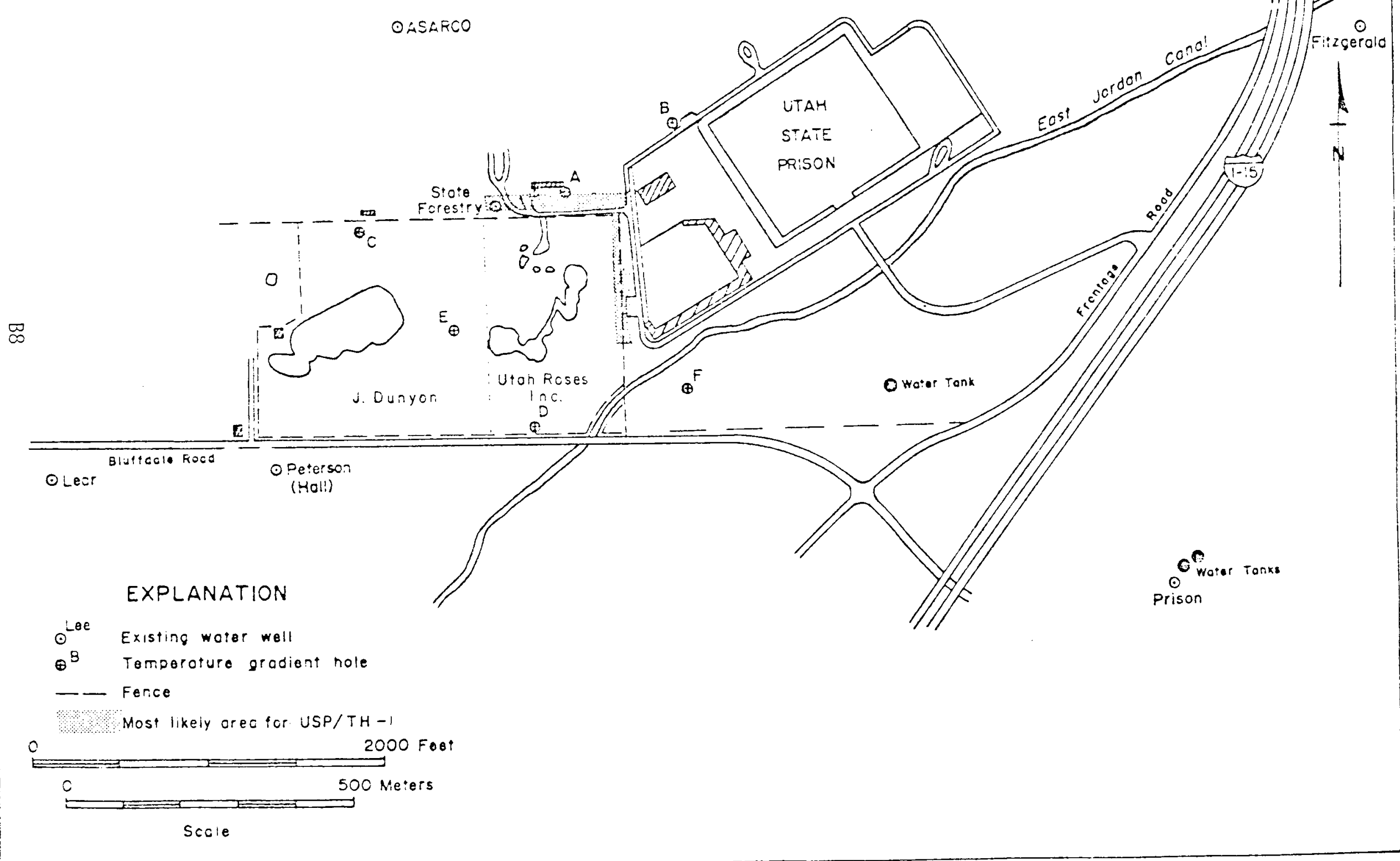


Appendix C: USGS Geothermal Well Operations 
UNITED STATES

DEPARTMENT OF THE INTERIOR

GEOLOGICAL SURVEY

CONSERVATION DIVISION

GEOTHERMAL RESOURCES OPERATIONAL ORDER NO. 2

Effective February 1, 1975

DRILLING, COMPLETION AND SPACING OF GEOTHERMAL WELLS

This order is established pursuant to the authority prescribed in 30 CFR 270.11 and in accordance with 30 CFR 270.14, 270.15, and 270.40. A11 wells shall be drilled in such a manner as to minimize damage to the environment and to protect life, health, property, usable ground waters and geothermal resources.

All exploratory wells drilled for geothermal resources shall be drilled in accordance with the provisions of this order. Initial development wells drilled for geothermal resources shall be drilled in accordance with the provisions of this Order, and these provisions shall continue in effect until field rules are issued. After field rules have been established by the Area Geothermal Supervisor (Supervisor), development wells in the individual fields shall be drilled in accordance with such rules.

Where sufficient geologic and engineering information is obtained through exploratory drilling, lessees may make application or the Supervisor may request the lessee to submit an application for the establishment of field rules. The supervisor may issue field rules at any time he deems appropriate upon failure of the lessee to timely file for such field rules.

All wells drilled under the provisions of this order shall have been included in an exploratory or development plan of operations as required under 30 CFR 270.34. Each Application for Permit to Drill (Form 9-331C) shall include all information required under $30 \mathrm{CFR} 270.71$, and shall include a notation of any proposed variances from the requirements of this order. All variances from the requirements specified in this order shall be subject to approval pursuant to 30 CER 270.48. References in this Order to approvals, determinations, and requirements for submitting of information or applications for approval are to those granted, made or required by the supervisor or his delegated representative. The lessee shall comply with the following requirements:

1. Well Casing. All wells shall be cased and cemented in accordance with the requirements of $30 \mathrm{CFR} 270.15$, and the application for permit to drill shall include the casing design safety factors for collapse, tension and burst. The permanent wellhead completion equipment shall be attached to the production casing or to the intermediate casing if the production casing does not reach to the surface except as otherwise authorized by the supervisor to meet special well conditions. All casing strings reaching the surface shall be cemented at a sufficient 
depth to provide adequate anchorage and support for the casing and any blowout prevention equipment required thereon. For the purpose of this order, the several casing strings in order of normal installation are (1) conductor, (2) surface, (3) intermediate and (4) production strings. The following casing setting depth requirements are general in nature and subject to variations to permit the casing to be set and cemented in a competent formation. The supervisor's determination of adequate casing setting depths shall be based upon all geologic and engineering factors including apparent geothermal gradients, depths and pressures of the various formations to be penetrated and all other pertinent information about the area. All depths in this order refer to true vertical depth (TVD) below ground level, unless otherwise specified.

A. Conductor Casing. This casing shall be set at a minimum depth of 15 metres ( 50 feet) and a maximum depth of 60 metres (200 feet) before drilling into shallow formations suspected or known to contain geothermal resources, non-condensible gases, or other mineral resources or upon encountering such formations.

B. Surface Casing. This casing shall be set at a depth equivalent to or in excess of ten percent of the proposed total depth of the well provided, however, that such setting depth shall be not less than 60 metres (200 feet) nor more than 400 metres (1,300 feet).

c. Intermediate Casing. This casing shall be set at any time when required by well conditions encountered in drilling below the surface casing such as anomalous pressure zones, uncased fresh water aquifers, cave-ins, washouts, lost circulation zones, rapidly increasing thermal gradients or other drilling hazards. If a liner is used as an intermediate string, the lap shall be tested by a fluid entry or pressure test to determine whether a seal between the liner top and the next larger casing string has been achieved. The liner overlap shall be a minimum of 30 metres ( 100 feet). The test shall be recorded on the drillex's log and may be witnessed by the supervisor. In the event of lap or casing failure during the test, the lap or casing must be repaired or recemented and successfully retested as required by the supervisor.

D. Production Casing. This casing may be set at the top of or through the potential producing zone and shall be set before completing the well for production. Production casing shall be run to the surface or lapped into the next larger casing string. The liner overlap, if utilized, shall be at least 30 metres ( 100 feet) and shall be tested, witnessed and recorded as in the case of intermediate casing hereinabove. In the event of lap or casing failure during the test, the lap or casing must be repaired or recemented and successfully retested as required 
by the Supervisor. Production casing shall normally be of consistent nominal outside diameter from the surface or from the top of the lap to the casing shoe. The surface casing shall not be used as production casing, unless otherwise authorized by the supervisor to meet special well conditions.

E. Cementing of Casing. The conductor and surface casing strings shall be cemented with a quantity of cement sufficient to fill the annular space back to the surface. The intermediate casing string shall likewise be cemented back to the surface or to the top of the lap if a liner is used as an intermediate string. Production casing shall be cemented with a high temperature resistant admix, unless waived by the supervisor and shall be cemented in a manner necessary to exclude, isolate or segregate overlying formation fluids from the geothermal resources zone and to prevent the movement of fluids into possible fresh water zones. Production casing shall be cemented back to the surface or, if lapped, to the top of the lap. A temperature or cement bond log may be required by the supervisor after setting and cementing the production casing and after all primary cementing operations if an unsatisfactory cementing job is indicated. Proposed well cementing techniques differing from the requirements of this paragraph will be considered by the superrisor on an individual well basis.

F. Pressure Testing. Prior to drilling out the casing shoe after cementing, all casing strings set to a depth of 152 metres (500 feet) or greater, except for conductor casing, shall be pressure tested to a minimum pressure of 69 bars (1,000 psi) or 0.045 bars/metre 10.2 psi/ft) whichever is greater. All casing strings set at a depth less than 152 metres (500 feet), except for conductor casing, shall be pressure tested to a minimum pressure of 35 bars ( $500 \mathrm{psi}$ ). Such test shall not exceed the rated working pressure of the casing or the blowout preventer stack assembly, whichever is lesser.

In the event of casing failure during the test, the casing must be repaired or recemented until a satisfactory test is obtained. A pressure decline of 10 percent or less in 30 minutes shall be considered satisfactory.

Casing test results shall be recorded on the driller's log and reported to the Supervisor within 30 days after the completion of such test. Advance notice of all casing and lap tests shall be given in sufficient time to enable the supervisor to be present to witness such tests. The casing and lap test reports shall give a detailed description of the test, including mud and cement volumes, lapse of time between running and cementing casing and testing, method of testing and test results. 
G. Directional Surveys.

(1) General. Deviation surveys (inclination from vertical or single shot) shall be taken on all wells during the normal course of drilling at intervals not to exceed 152 metres $(500$ feet). The Supervisor may require a directional survey giving both inclination and azimuth or a dipmeter to be obtained on all wells. In calculating all surveys, a correction from true north to Lambert-Grid north shall be made after making the magnetic to true north correction. All surveys shall be filed with the Supervisor. Where directional surveys are required, composite surveys shall be filed with the Supervisor showing the interval from the bottom of the conductor casing to total depth.

(2) Vertical Wells. Wells are considered vertical if inclination does not exceed an average of five degrees from the vertical. The Supervisor may require a directional survey giving both inclination and azimuth at intervals not exceeding 30 metres (100 feet) between stations prior to, or upon, setting any casing string or liner (except conductor casing) and at total depth on any vertical well drilled in close proximity to lease boundaries or areas with an unstable land surface, highly faulted or steeply dipping beds, or in areas of suspected abnormal formation pressures.

(3) Directional Wells. Wells are considered directional if inclination exceeds an average of five degrees from the vertical. Directional surveys giving both inclination and azimuth shall be obtained at intervals not to exceed 30 metres ( 100 feet) between statior.s prior to, or upon, setting any casing string or liner (except conductor casing) and at total depth.

2. Blowout Prevention Equipment and Procedures. AlI necessary precautions shall be taken to keep all wells under control at all times, utilize trained and competent personnel, and utilize properly maintained equipment and materials. Blowout preventers and related well control equipment shall be installed, tested immediately thereafter and maintained ready for use until drilling operations are completed. Certain components, such as packing elements and ram rubbers, shall be of high temperature resistant material as necessary. All kill lines, blowdown Iines, manifolds and fittings shall be steel and shall have a temperature derated minimum working pressure rating equivalent to the maximum anticipated wellhead surface pressure. Subject to subparagraphs (A) and (B) hereinbelow blowout prevention equipment shall have manually operated gates and hydraulic actuating systems and accumulators of sufficient capacity to close all of the hydraulically-operated equipment and have a minimum pressure of 69 bars ( 1,000 psi) remaining on the accumulator. Dual control stations shall be installed with a high 
pressure backup system. One control panel shall be located at the driller's station and one control panel shall be located on the ground at least 15 metres (50 feet) away from the wellhead or rotary table. Air or other gaseous fluid drilling systems shall have blowout prevention assemblies. Such assemblies may include, but are not limited to, a rotating head, a double ram blowout preventer or equivalent, a banjo-box or an approved substitute therefor and a blind ram blowout preventer or gate valve, respectively. Exceptions to the requirements of this paragraph will be considered by the Supervisor only for certain geologic and well conditions such as stable surface areas with known low subsurface formation pressures and temperatures.

A proposed blowout prevention program and a blowout contingency plan including proposed containment, public health and safety and cleanup measures shall be submitted with the Application for Permit to Drill (Form 9-331C).

A. Conductor Casing. Before drilling below this string, at least one remotely controlled hydraulically-operated expansion type preventer or an acceptable alternative, approved by the supervisor, including a drilling spool with side outlets or equivalent, shail be installed. A kill line and blowdown line with appropriate fittings shall be connected to the drilling spool.

B. Surface, Intermediate and Production Casing. Before drilling below any of these strings, the blowout prevention equipment shall include a minimum of:

(1) One expansion-type preventer and accumulator or a rotating head;

(2) A manual and remotely controlled hydraulically-operated double ram blowout preventer or equivalent having a temperature derated minimum working pressure rating which exceeds the maximum anticipated surface pressure at the anticipated reservoir fiuid temperature;

(3) A drilling spool with side outlets or equivalent;

(4) A fillup line:

(5) A kill line equipped with at least one valve; and

(6) A blowdown line equipped with at least two valves and securely anchored at all bends and at the end.

C. Testing and Maintenance. Ram-type blowout preventers and auxiliary equipment shall be tested to a minimum of 69 bars 1,000 psi) or to the working pressure of the casing or assembly, whichever is the lesser. Expansion-type blowout preventers shall be tested to 70 
percent of the above pressure testing requirements.

The blowout prevention equipment shall be pressure tested:

(1) When installed;

(2) Prior to drilling out plugs and/or casing shoes;

(3) Not less than once each week, alternating the control stations; and

(4) Following repairs that require disconnecting a pressure seal in the assembly.

During drilling operations blowout prevention equipment shall be actuated to test proper functioning as follows:

(1) Once each trip for blind and pipe rams but not less than once each day for pipe rams; and

(2) At least once each week on the drill pipe for expansion-type preventers.

All flange bolts shall be inspected at least weekly and re-tightened as necessary during drilling operations. The auxiliary control systems shall be inspected daily to check the mechanical condition and effectiveness and to ensure personnel acquaintance with the method of operation. Blowout prevention and auxiliary control equipment shall be cleaned, inspected and repaired, if necessary, prior to installation to assure proper functioning. Blowout prevention controls shall be plain'y labeled, and all crew members shall be instructed on the function and operation of such equipment. A blowout prevention drill shall be conducted weekly for each drilling crew. All blowout prevention tests and crew drills shall be recorded on the driller's log.

D. Related Well Control Equipment. A full opening drill string safety valve in the open position shall be maintained on the rig floor at all times while drilling operations are being conducted. A kelly cock shall be installed between the kelly and the swivel.

3. Drilling Fluid. The properties, use and testing of drilling fluids and the conduct of related drilling procedures shall be such as are necessary to prevent the blowout of any well. Sufficient drilling fluid materials to ensure well control shall be maintained in the field area readily accessible for use at all times. 
A. Drilling Fluid Control. Before pulling drill pipe, the drilling fluid shall be properly conditioned or displaced. The hole shall be kept reasonably full at all times, however, in no evert shall the annular mud level be deeper than 30 metres ( 100 feet) from the rotary table when coming out of the hole with drill pipe. Mud cooling techniques shall be utilized when necessary to maintain mud characteristics for proper well control and hole conditioning.

B. Drilling Fluid Testing. Mud testing and treatment consistent with good operating practice shall be performed daily or more frequent-Iy as conditions warrant. Mud testing equipment shall be maintained on the drilling rig at all times.

The following drilling fluid system monitoring or recording devices shall be installed and operated continuously during drilling operations, with mud, occurring below the shoe of the conductor casing. No exceptions to these requirements will be allowed without the specific prior permission of the supervisor:

(1) High-low level mud pit indicator including a visual and audiowarning device;

(2) Degassers, desilters and desanders;

(3) A mechanical, electrical or manual surface drilling fluid temperature monitoring device. The temperature of the drilling fluid going into and coming out of the hole shall be monitored, read and recorded on the driller's or mud log for a minimum of every 9 metres (30 feet) of hole drilled below the conductor casing; and

(4) A hydrogen sulfide indicator and alarm shall be installed in areas suspected or known to contain hydrogen sulfide gas which may reach levels considered to be dangerous to the health and safety of personnel in the area.

c. Monitoring. From the time drilling operations are initiated and until the well is completed or abandoned, a member of the drilling crew or the toolpusher shall monitor the rig floor at all times for surveillance purposes, unless the well is secured with blowout preventers or cement plugs.

4. Well Logging. All wells shall be logged with an induction electric log or equivalent from total depth to the shoe of the conductor easing. The Supervisor may grant an exception to this requirement when well conditions make it impractical or impossible to meet the above requirements. 
A. Electric Logs. The lessee shall furnish to the Supervisor two legible exact copies of all logs run, within 30 days after completion of drilling operations on each well. Two copies of field prints of such logs shall be made immediately available to the supervisor upon his request. Two copies of chemical analyses of geothermal fluids or other similar services performed shall be submitted to the supervisor within 30 days after such services are completed.

B. Lithologic Logs. Two legible exact copies of core analysis reports and lithologic (mud) logs shall be submitted to the Supervisor within 30 days after the completion of such reports or logs, when such services are used. However, daily logs shall be made available to the Supervisor immediately upon the completion of such daily logs upon his request.

5. Wellhead Equipment and Testing.

A. Completions. All wellhead connections shall be fluid pressure tested to the API or ASA working pressure rating. Cold water is recommended as the testing fluid. Welding of wellhead connections shall be performed by a certified welder using materials in conformance with ASTM specifications.

B. Wellhead Equipment. All completed wells shall be equipped with a minimum of one casinghead with side outlets, one master valve and one production valve, unless otherwise authorized by the Supervisor. All casingheads, Christmas trees, fittings and connections shall have a temperature derated working pressure equal to or greater than the surface shut-in pressure of the well at reservoir temperature. Packing, sealing mediums and lubricants shall consist of materials or substances that function effectively at, and are resistant to, high temperatures. Wellhead equipment, valves, flanges and fittings shall meet minimum ASA standards or minimum API Standard 6A specifications. Casinghead connections shall be made such that fluid can be pumped between casing strings.

C. Testing. Any well showing sustained casinghead pressure or leaking of geothermal fluids between casing strings shall be tested to determine the origin of the failure, when such failure point is not otherwise determinable, and corrective measures shall be taken.

6. Well Spacing. No producing interval of any well shall be located within 30 metres (100 feet) of the outer boundaries of the leased lands, except where approved by the Supervisor. No surface location of a well shall be located within 15 metres (50 feet) of the boundary of any legal subdivision unless otherwise authorized by the supervisor. The Supervisor may approve or prescribe such well 
spacing as he determines to be necessary for the p:oper deve-opment of the geothermal resources in accordance with the provisions of 30 CFR 270.15 .

Appendix D: Utah Division of Water Rights:

Rules and Regulations for Geothermal Wells 


\begin{abstract}
RULES AND REGULATIONS OF THE DIVISION OF WATER RIGHTS

FOR WELLS USED FOR THE DISCOVERY AND PRODUCTION OF GEOTHERMAL ENERGY IN THE STATE OF UTAH
\end{abstract}

ADOPTED - PIARCH 1, 1978 


\section{TABLE CF CONTEUTS}

RULE 1 - GEIERAL PRO!ISIC:IS

1-1 Authority

1-2 Definitions

RULE 2 - DRILLING

2-1 Applications

2-2 Fees

2-3 Bonds

2-4 Well Spacing

2-5 Identification

2-6 Unit Agreements

2-7 Casing Requirements

2-8 Electric Logging

RULE 3 - BLOW-OUT PREVENTION

3-1 General

3-2 Requirements Using Mud as the Drilling Fluid

3-3 Requirements Using Air as the Drilling Fluid

RULE 4 - RECORDS

4-1 General

4-2 Records to be filed with the Division

4-3 Confidential Status

4-4 Inspection of Records

RULE 5 - INJECTION WELLS

\section{5-1 Construction}

5-2 Surveillance

RULE 6 - ABANDONMENT

6-1 Objectives

6-2 General Requirements

RULE 7 - MAINTENANCE

7-1 General

$7-2$ Corrosion.

7-3 Tests

RULE 8 - TENPERATURE GRAOIEIIT VELLS

8-1 General

8-2 Information

8-3 Conditions 
(Table of cortents Contin:sed)

RULE 9 - ENVIRONHENT

9-1 General

RULE 10 - HEARINGS, APPEALS, PENALTIES 


\section{PULES ANO REGULATIOHS OF \\ THE DIYISION OF HATER RIGHTS \\ FOR WELLS USED FOR THE DISCOVERY ATID PEODUCTIOUY OF \\ GEOTHERMAL ENERGY IN THE STATE OF UTAH}

\section{RULE 1 - GENERAL PROVISIONS}

1-1 Authority: The Division of Water Rights is given jurisdiction and authority to require that all wells for the discovery and production of water to be used for geothermal energy production of water in the State of Utah, be drilled, operated, maintained, and abandoned in such manner as to safeguard life, health, property, the public welfare, and to encourage maximum economic recovery. $(73-1-20$ UCA)

1-2 DEFIMITIONS:

a. "Applicant" means any person submitting an application to the Division of Water Rights to appropriate water, brine or steam for geothermal purposes and for the construction and operation of any well or injection well.

b. "BOPE" is an abbreviation for Blow-Out Prevention Equipment which is designed to be attached to the casing in a gaothermal well in order to prevent a blow-out.

c. "Completion." A well is considered to be completed thirty days after drilling operations have ceased uniess a suspension of operation is approved by the Division, or thirty days after it has commenced producing a geothermal resource, whichever occurs first, unless drilling operations are resumed before the end of the thirty-day period or at the end of the suspension.

d. "Correlative Rights" means the owners' or operators' just and equitable share in the geothermal resource.

e. "Division" means the Division of Water Rights, Department of Natural Resources, State of Utah.

f. "Drilling Logs" means the recorded description of the lithologic sequence encountered in drilling a well.

g. "Orilling Oparations" means the actual drilling, redrilling, or recompletion of the well for production or injection including the running and cementing of casing and the installation of well head equipment. Drilling operations do not include perforating, logging, and related operations. 
h. "Exploratory Weli" means a we!! drilled for the discovery and/or evaluation of geothermai rescurces either in an established geothermal field or in unexplored areas.

i. "Geothermal Area" means the same general land area wich in its subsurface is underlaid 0. razsonably appears to ba underlaid by geothermal resources from or in a reservoir, pool, or other source or interrelated sources.

j. "Geothermal Field" means an area dosignated by the Division which contains a well or wells capable of commercial production of geothermal resources.

k. "Geothermal Resource" means the natural heat energy of the earth, the energy in whatever form which may be found in any position and at any depth below the surface of the earth, present in, resulting from, or created by, or which may be extracted from such natural heat and all minerals in solution or other products obtained from the material medium of any geothermal resource.

1. "Injection Well" means any special well, converted producing well, or reactivated or converted abandoned well employed for injecting material into a geothermal area or adjacent area to maintain pressures in a geothermal reservoir, pool, or other source, or to provide new material to serve as a material medium therein, or for reinjecting any material medium or the residue thereof, or any by-product of geotherma? resource exploration or development into the earth.

m. "Material Medium" means any substance including, but not limited to, naturally heated fluids, brines, associated gases and steam in whatever form, found at any depth and in any position below the surface of the earth, which contains or transmits the natural heat energy of the earth, but excluding petroleum, oil, hydrocarbon gas, or other hydrocarbon substances.

n. "Notice" means a statement to the Division that the applicant intends to do work.

o. "Operator" means any person drilling, maintaining, operating, pumping, or in control of any well. The term operator also includes owner when any well is or has been or is about to be operated by or under the direction of the owner.

p. "Owner" means the oiner of the geothermal lease or well and includes operator when any well $i$ operated or has been operated or is about to be operated by any person other than the owner. 
q. "Person" miesns any individual naturái person, general or limited partnership, joint venture, association, cooperdtive organization, corporation, whetner domestic or foreign, agency or subdivision oi this or any other state or municipal or quasi-municipai entity whether or rot it is incorporated.

$r$. "Production Heil" means any well wish is comercially producing or is intended for comercial production of a geothermal resource.

s. "State Engineer" is the Director of the Division of Water Rights, which is the agency having general adninistrative supervision over the waters of the State. The duties of this Division are primarily set forth in Title 73 , Chapters 1 through 6, inclusive, Utah Code Annotated, 1953, as amended.

$t$. "Suspension of Operations" means the cessation of drilling, redrilling, or alteration of casing before the well is officially abandoned or completed. All suspensions must be authorized by the Division.

u. "Waste" means any physical waste including, but not limited to:

1. Underground waste resulting from inefficient, excessive, or improper use, or dissipation of geothermal energy, or of any geothermal resource pool, reservoir, or other source; or the locating, spacing, constructing, equipping, operating, or producing of any well in a manner which results, or tends to result in reducing the quantity of geothermal energy to be recovered from any geothermal area in the State.

2. The inefficient above-ground transporting and storage. of geothermal energy; and the locating, spacing, equipping, operating, or producing of any well or injection well in a manner causing or tending to cause unnecessary oi excessive surface loss or destruction of geothermal energy; the escape into the open air from a well of steam or hot water in excess of what is reasonably necessary in the efficiant development or production of a well.

v. "We17" means any well drilled for the discovery or production of geothermal resources or any well on lands producing seothermal resources or rassonably presumed to contain geothermal resources, or any speciai vall, converted producing well or reactivated or converted abandoned well employed for reinjecting gestherma? resourcas or the residue thereof. 


\section{QULE 2 - ORILLING}

2-1 Applications:

2-1-1 Applications to drill for Geothermai Pesources.

Any person, owner or operator, who proposes to drill a viell for the production of geothermal resources or to drill an injaction well shall first apply to the Division in accordance aith Chapter 73-3, UCA. Applications to appropriate water for geothermal purposes will be processed and investigated by the Division, and if they meet the requirements of Section 73-3-8, UCA, they will be approved by the State Engineer on a well-to-well basis or as a group of wells which comprise an operating unit and have like characteristics.

Appropriation of water for geothermal purposes shall not be considered mutually interchangable with water for any other purpose. Water, brine, steam or condensate produced during a geothermal operation may be subject to further appropriation if physical conditions permit.

2-1-2 Plan of Operations:

Before drilling an exploratory or production well, the applicant shall submit a plan of operations to the State Engineer for his approval. The plan shall include:

a. Location, elevation and layout.

b. Lease identification and Well Number.

c. Tools and equipment description including maximum capacity and depth rating.

d. Expected depth and geology.

e. Drilling, mud, cementing and casing program.

f. BOPE installation and test.

g. Logging, coring and testing program.

h. Methods for disposal of vaste materials.

i. Environmental considerations.

j. Eirergency procedures.

k. Sich other information is the State Engineer ray require. 
2-1-3 Application to deepen or modify an existing well.

If the owner or cperator plans to deepen, redrill, plug, or perform any operation that will in any manner modify the weli, an application shall be filed with the Dijision and written approral must be recaived prior to beginning : or's; hovever, in an emergancy, the owner or operator may take action to prevent damage without receiving prior uritten approval from the Division, but in such cases the owner or operator shall report his action to the Division as soon as possible.

2-1-4 Application for permit to convert to injection.

If the owner or operator plans to convert an existing geothermal well into an injection well with no change of mechanical condition, written request shall be filed with the Division and written approval must be received prior to beginning injection.

2-1-5 Amendment of permit.

No changes in the point of diversion, place or nature of use shall be allowed until an amendment to such application is approved by the State Engineer in accordance with Section 73-3-3 UCA.

2-1-6 Notice to other agencies.

Notice of applications, permits, orders, or other actions received or issued by the Division may be given to any other agency or entity which may have information, comments, or interest in the activity involved.

2-2 Fees: Any application filed with the State Engineer shall be accompanied by a filing fee in accordance with 73-2-14 UCA.

2-3 Bonds:

2-3-1 Any operator having approval to drill, re-enter, test, lalter or operate a well, prior to any construction or operation, shall file with the Division of Water Rights and obtain its approval of a surety bond, payabie to the Division of Water Rights for not less than $\$ 10,000$ for each individual well or $\$ 50,000$ for all wells. The bond shall be on a form prescribed by the Division and shall be conditioned on faithful compliance with all statutes and these rules and regulations.

2-3-2 Bonds remain in force for the life of the well or wells and may not be released until the well or wills are properly abandoned or another valid bond is substituted therefore.

2-3-3 Transfer of property does not relasse the bond. If any property is transferred and the principa? desires to be released from his bond, the operator shall: 
a. Assign or transiar obinership in the ranner orescribed in Sections 73-1-10 and 73-3-18, LCA, identifying the right by application niriver, well nunjer as:d/or location and,

b. Provida the Oivision with a declaration in writing from the assignee or transieree that he accepts the assignment and tenders his own bond therewith or therein accepts responsibility under his blanket bond on file with the Division.

2-4 Well Spacing:

2-4-1 Any well drilled for the discovery or production of geothermal resources or as an injection well shall be located 100 feet or more from and within the outer boundary of the parcel of land on which the well is situated, or 100 feet or more from a public road, street, or highway dedicated prior to the commencement of drilling. This requirement may be modified or waived by the State Engineer upon written request.

2-4-2 For several contiguous parcels of land in one or different ownerships that are operated as a single geothermal field, the term outer boundary line means the outer boundary line of the land included in the field. In determining the contiguity of any such parcels of land, no street, road, or alley lying within the lease or field shall be determined to interrupt such contiguity.

2-4-3 The State Engineer shall approve the proposed vell spacing programs or prescribe such modifications to the programs as he deems necessary for proper development giving consideration to such factors as, but not 7 imited to, topographic characteristics of the area, the number of wells that can be economically drilled to provide the necessary volume of geothermal resources for the intended use, protecting correlative rights, minimizing well interference, unreasonable interference with multiple use of lands, and protection of the environment.

2-4-4 Directional drilling.

Where the surface of the parcel of land is unavailable for drilling, the surface well location may be located upon property which may or may not be contiguous. Such surface well locations shall not be less than 25 feet from the outer boundary of the parcel on which it is located, nor less than 25 feet from an existing street or road. The production or injection interval of the well shall not be less inan 100 feet from the outer boundary of the parcel into which it is drilled. Directional surveys must be filed with the Division for all wells directionally drilled. 
2-5 Identification: Each vill being drilles or frijled and not abancinad shatl be identified by a durable sien posted in a conspicuous place near the weli. The lettering siall be large enougin to be legible at 50 feet under normal conditions and shall show the name of the applicant, vell number, location by 10-acre tract $\left(\frac{1}{4}-\frac{1}{4}-\frac{1}{4}\right.$ Section, Township and Range), and name of lease.

The well number shall be according to the modified Kettleman Well Numbering System adopted by the U. S. Geological Survey.

2-6 Unit Agreements: At the request of any interested party or on his own initiative, the State Engineer may establish a unit plan or agreement for a geothermal area to prevent waste, protect correlative rights and avoid drilling unnecessary wells. Proper notice to interested parties must be given and a hearing held before the State Engineer before the unit may be created.

2-7 Casing Requirements:

2-7-1 General.

All wells shall be cased in such a manner as to protect or minimize damage to the environment, usable ground waters and surface waters, geothermal resources, 1 ife, health, and property. The permanent well head completion equipment shall be attached to the production casing or to the intermediate casing if production casing does not reach to the surface.

Specifications for casing strings shall be determined or approved on a well-to-well basis. All casing strings reaching the surface shall provide adequate anchorage for blowout-prevention equipment, hole pressure control and protection for all natural resources. The casing requirements given are general but should be used as guidelines in submitting proposals to drill.

2-7-2 Conductor Casing.

A minimum of 40 feet of conductor casing shall be installed. The annular space is to be cemented solid to the surface. A 24-hour cure period for the grout must be allowed prior to drilling out the shoe unless additives approved by the State Engineer are used to obtain early strength. An annular blowout preventer shall be installed on all exploraiory wells and on developrent wells when deened necessary by the Division. For 10:i-temperature geothermal wells (less than $90^{\circ}$ C) this requirement may be raduced or waived by the State Enginear.

2-7-3 Surface Casing.

Except in the case of 10:1-temperature geothermal wells, the 
suriace casing hole shall be logged with an induction electrical log, or equivalent, before running casing or by gainia-neutron

log. This requirement may vary from area to risaz, depending upon the amount of pre-existing subsurface gaological date available, and may not be requirad under certain condicions. However, permission to omit this requirement must be grentes oy the Division prior to running surface casing.

Surface casing shall provide for control of formation fluids, for protection of shallow usable ground water (if any) and for adequate anchorage for blowout-prevention equipment. All surface casing shall be cemented solid to the surface. A 26-hour cure period shall be allowed prior to drilling out the shoe of the surface casing unless additives approved by the State Engineer are used to obtain eariy strength.

2-7-3-1 Length of Surface Casing.

(a) In areas where subsurface geological conditions are variable or unkno:m, surface casing in general shall be set at a depth equaling or exceeding 10 percent of the proposed total depths of wells drilled in such areas.. A minimum of surface casing shall be set through a sufficient series of low permeability, competent lithologic units (such as claystone, siltstone, basalt, etc.) to ensure a solid anchor for blowoutprevention equipment and to protect usable ground water and surface water from contamination. A second string or intermediate casing may be required if the first string has not been cemented through a sufficient series of low permeability, competent lithologic units and either a rapidly increasing geothermal gradient or rapidly increasing formation pressures are encountered.

(b) In areas of known high formation pressure, surface casing shall be set at a depth approved by the Division after a careful study of geological conditions.

(c) Within the confines of designated geothermal fields, the depth to which surface casing shall be set shall be approved by the Division on the basis of known field conditions.

(d) These requirements may be reduced or waivad by the State Engineer for low-temperature geothermal wells.

\section{2-7-3-2 Mud Raturn Temperatures.-}

The temperature of the raturn mud shall be monitored regularly during the drilling of the surface casing ho? a. Either a continuous temperature monitoring device shali bo installed and 
maintained in working condition, or the temperdture shall be read manualiy. In either case, return mud terperature shall be logged after each joint of pipe has been drilled down (30 feet).

2-7-3-3 Bloivout-Prevention Equipment.

BOPE capable of shutting-in the well during any operation shall be installed on the surface casing and maintained ready for use at all times. BOPE pressure tests shall be witnessed by Division personnel on all exploratory wells prior to drilling out the shoe of the surface casing. The decision to require and witness BOPE pressure tests on all other wells shall be made on a well-to-well basis. The Division must be contacted 24 hours in advance of a scheduled pressure test. The State Engineer may give verbal permission to proceed with the test upon request by the operator.

2-7-4 Intermediate Casing.

Intermediate casing shall be required for protection against unusual pressure zones, cave-ins, wash-outs, abnormal temperature zones, uncontrollable lost circulation zones or other drilling hazards. Intermediate casing strings shall be cemented solid to the surface or to the top of the liner hanger whenever the intermediate casing string is run as a liner. The liner lap shall be pressure tested prior to resumption of drilling.

2-7-5 Production Casing.

Production casing may be set above or through the producing or injection zone and cemented above the injection zones. Sufficient cement shall be used to exclude overlying formation fluids from the geothermal zone, to segregate zones and to prevent movement of fluids behind the casing into zones that contain usable ground water. Production casing shall either be cemented solid to the surface or lapped into intermediate casing, if run. If the production casing is lapped into an intermediate casing, the casing overlap shall be at least 100 feet, the lap shall be cemented solid, and it shall be pressure tested to ensure its integrity.

2-8 Electric Logging:

All wells, except observation wells for monitoring purposes only, shall be logged with an induction electrical log or equivalent or garma-neutron log from the bottom of the hole to the bottom of the conductor pipe. This requirement may be modified or waived by the Division upon written request.

RULE 3 - ELOHOUT PREVENTION

3-1 General.

3-1-1 Elowout-Prevention Equipent (BOPE) installations shall include 
high temperature-rated packing units and ram rubbers, if ardilab!e, and shall have a inininum working-pressure rating equal to or grazaer than the lesser of:

a. A pressure equal to the product of the depth of the BOPE anchor string (usually the surfece casing) in feat timss one (1) psi per foot.

b. A pressure equal to the rated burst pressure of the BOPE anchor string.

c. A pressure equal to 2,000 psi.

Specific inspections and tests of the BOPE may be made by the Division. The requirements for such tests will be included in the Division's answer to the notice of the intention to drill.

3-1-2 A Division employee may be present at the well at any time during the drilling.

3-1-3 A logging unit equipped to regularly record the following data shall be installed and operated continuously after drilling out the shoe of the conductor pipe and until the well has been drilled to the total depth.

a. Drilling mud temperature (in and out).

b. Drilling mud pit level.

c. Drilling mud pump volume.

d. Drilling mud weight.

e. Drilling rate.

f. Hydrogen sulfide gas volume (with alarm).

The Division may waive the requirement for installation of a logging unit on evidence that the owner or operator has engaged a qualified mud engineer to monitor, $\log$ and record the data specified in the above subparagraphs a. through $d$. In such event, the drilling rate required in subparagraph e. shall be logged with standard industry recording devices, and hydrogen sulfide monitoring and safety equipment shall be provided whenever needed to satisfy the requirement of subparagraph $f$.

3-2 Reguirements Using llud as the Drilling Fluid.

The following requirements are for exploratory areas, unstable areas containing fumeroles, geysers, hot springs, nud pots, etc., and for fields with a history of lost circulation, a blowut, and/or 
zone pressures lass than 1000 psi. Thase requirements may ía reduced by the state Engineer where the jeothermal formations are known to be shalio: and of low pressire and temperature.

a. An annular BOPE and a spool, fitted with a losi-pressura safety pop-off and blo:1-do:y line, installed on tis a conductor pipe may be required to ensure against possible gas blowouts during the drilling of the surface casing hole.

b. Annular BOPE and pipe-ram/blind-ram BOPE with a minimum working pressure rating of 2,000 psi shall be installed on the surface casing so that the well can be shut-in at any time. The double-ram preventer shall have a mechanical locking device.

c. A hydraulic actuating system utilizing an accumulator of sufficient capacity and a high pressure auxiliary back-up system. This total system shall be equipped with dual controls: one at the driller's station and one at least 50 feet away from the well head.

d. Kelly cock and standpipe valve.

e. A fill-up line installed above the BOPE.

f. A kill line installed below the BOPE, leading directly to the mud pumps and fitted with a valve through which cement could be pumped if necessary.

g. A blow-down line fitted with two valves installed below the BOPE. The blow-down line shall be directed in such a manner so as to permit containment of produced fluids and to minimize any safety hazard to personnel.

h. All lines and fittings shall be steel and have a minimum working-pressure rating of at least that required of the BOPE.

i. The temperature of the return mud during the drilling of the surface casing hole shall be monitored regularly. Either a continuous temperature monitoring device shall be installed and maintained in working condition, or the temperature shall be read manually. In either case, return mud temperatures shall be logged after each joint of pipe is drilled down (every 30 feet).

3-3 Requirements Using Air as the Drilling Fluid.

The following requirements are for areas where it is known that dry steam exists at depth and/or formation pressures are less than hydrostatic: 
a. A rotating-head installed at the top of the BOpe stack.

b. A pipe-ram/blind-ram BCPE, with a minimum working-uressure rating of 1,000 psi, installed below the rotating-nazd so that the well can be sriut-in at any time.

c. A banjo-box or mud-cross stedm diversion unit installed below the double-ram BOPE fitted with a mufiler capable of lowering sound emissions to within State standards.

d. A blind-ram BOPE, with a minimum working-pressure rating of 1,000 psi, installed below the banjo-box or mud-cross so that the well can be shut-in while removing the rotating-head during bit changes.

e. A master gate valve, with a minimum :orking-pressure rating of 600 psi, installed belo:l the blind-ram so that the well can be shut-in after the well has been completed, prior to removal of the BOPE stack.

f. All ram-type BOPE shall have a hydraulic actuating system utilizing an accumulator of sufficient capacity and a high-pressure backup system.

g. Dual control stations for hydraulic backup system: one at the driller's station and the other at least 50 feet away from the well head.

h. Float and standpipe valves.

i. A kill line installed below the BOPE, leading directly to the mud pumps and fitted with a valve through which cement could be pumped if necessary.

j. All lines and fittings must be steel and have a minimum working-pressure rating of $1,000 \mathrm{psi}$.

\section{RULE 4 RECORDS}

4-1 General: The owner or operator of any well shall keep or cause to be kept a careful and accurate log, core record, and history of the drilling of the well. These records shall be kept in the nearest office of the owner or operator or at the vell site and together witi all other reports of the ounar and operator regarding the well shal? be subject to inspection by the Division during business hours. All records, unless otharwise specified, must be filed with the Division within ninety (90) days after completion of the well.

4-2 Records to be Filed with the Division: 
L-2-1 Drilling Logs and Core Record - the drilling log sidall include the lithologic characteristics and ieptas of formations encountered, the deptin and temperatures of water-besring and steam-bezing strata, the temperatures, chemical compcsitions and other chemical and physical characteristics of fluids encountered fron tire to time so far as ascertainad. The core record shall sripi tha depth, lithologic character, and fluid content of cores obiained so far as determined.

4-2-2 Well History - the history shall describe in detail in chrorological order on a daily basis all significant operations carried out and equipment used during all phases of drilling, testing, compietion, and abandonment of any well.

4-2-3 Well Summary Report - the well summary report shall accompany the core record and well history reports. It is designed to show data pertinent to the condition of a well at the time of completion of work done.

4-2-4 Production Records - the owner or operator of any well producing geothermal resources shall file with the Division on or before the tenth day of each month for the preceding month, a statement of production utilized in such a form as the Division may designate.

4-2-5 Injection Records - the ouner or operator of any well injecting geothermal fluids or waste water for any purpose shall file with the Division on or before the tenth day of each month for the preceding month a report of the injection in such form as the Division may designate.

4-2-6 Electric Logs and Directional Surveys if Conducted - electric logs and directional surveys shall be filed with the Division within ninety days of completion, cessation of drilling operations, excluding any approved suspension of operation, or abandonment of any well. Like copies shall be filed upon recompletion of any well. Upon a showing of hardship, the Division may extend the time within which to comply for a period not to exceed one year.

4-3 Confidential Status: Any reports, logs, records, or histories filed with the Division shall not be available for public inspection and shall be kept confidential by the Division unless agreed to by the owner, provided, however, that the Division may use any such reports, logs, records, or histories in any action in any court to enforce the provisions of the Ceothermal Act or any o:der or regulation alopted hereunder. Tha following information fiay be made public by tha Division:

(a) Owner or operator's name.

(b) :all designation or number. 
(c) Elevation of derrick iloor or ground elevdtion.

(d) Location of well.

(e) The application and all information pertaining to it, including its current status.

4-4 Inspection of Records: The records filed by an operator with the Division shall be open to inspection only to those authorized in writing by the operator and to designated Division personnel. The records of any operator filed for a completed or producing well that has been transferred by sale, lease, or otherwise shall be available to the new owner or lessee for his inspection or copying and shall be available for inspection or copying by others upon written authorization of such new owner or lessee.

\section{RULE 5 - INJECTION WELLS}

5-1 Construction: The owner or operator of a proposed injection wall or series of injection wells shall provide the Division with such information it deems necessary for evaluation of the impact of such injection on the geothermal reservoir and other natural resources. Such information shall include existing reservoir conditions, method of injection, source of injection fluid, estimates of daily amount of material medium to be injected, zones or formations affected, and analysis of fluid to be injected and of the fluid from the intended zone of the injection, if available.

5-2 Surveillance:

5-2-1 When an operator or owner proposes to drill or modify an injection well or convert a well to an injection well, he shall be required to demonstrate to the Division by means of a test that the casing has complete integrity. This test shall be conducted in a method approved by the Division.

5-2-2 To establish the integrity of the annular cement above the shoe of the casing, the owner or operator shall make sufficient survays within thirty days after injection is started into a well to prove that all the injected fluid is confined to the intended zone of injection. Thereafter, such surveys shall be made at lasst every two years or more often if necessary. The Division shall be notified 43 hours in advance of such surveys in order that a representative may be present if deemed necessary. If in the State Engineer's opinion such tesis are not necessary, he may grant a waiver exempting the operator from such tests.

5-2-3 After a well has been placed into injection, the injection well site will bo visited periodica? ly by Division personnel. The operator or owner will be notified of any necessary ramedial work. Unless modified by the State Engineer, this work must be performed :y thin ninety days of approval for the injection well, or approval for the injection well issued by the Division will be rescinded. 


\section{RULE 6 - ABAMOOMHE:T AND SEALIHG}

6-1 Objactives: The objectives of abanconment are to block interzonai migration of fluids so as to:

a. Prevent contamination of fresh waters or other natural resources.

b. Prevent danage to geotherma? reservoirs.

c. Prevent loss of reservoir energy.

d. Protect life, health, environment and property.

6-2 General Requirements: The following are general requirements which are subject to review and modification for individual wells or field conditions:

a. A notice of intent to abandon geothermal resource wells is required to be filed with the Division five days prior to beginning abandonment procedures. A permit to abandon may be given orally by the State Engineer provided the operator submits a written request for said abandonment within 24 hours of the oral request.

b. A history of geothermal resource wells shall be filed within sixty days after completion of abandonment procedures.

c. All wells abandoned shall be monumented and the description of the monument shall be included in the history of well report. Such monument shall consist of a fourinch diameter pipe 10 feet in length of which four feet shall be above ground. The remainder shalt be imbadded in concrete. The applicant's name, application number, and location of the well shall be shown on the monument. An abandoned well on tilled land shall be marked in a manner approved by the State Engineer.

d. Good quality, heavy drilling fluid shall be used to replace any water in the hole and to fill all portions of the hole not plugged with cement.

e. All cement plugs :ith a possible exception of the surface plug shall be pumpad into the hole through drill pipe or tubing.

f. All open annuli shall be filled solid with cement to the surface. 
g. A minimum of 100 Feet of comant shil be emplecad straddling the interface or transition zone at the base of ground water aquifers.

h. One hundred feet of cement shall straddle the placerrent of the shoe plif on all casings including conductor pipe.

i. A surface plug of either neat cement or concrete mix shall be in place from the top of the casing to at least 50 feet below the top of the casing.

j. All casing shall be cut off at least five feet below land surface.

k. Cement plugs shall extend at least 50 feet over the top of any liner installed in the well.

1. Injection wells are required to be abandoned in the same manner as other wells.

m. Other abandonment procedures may be approved by the Division if the owner or operator can demonstrate that the geothermal resource, ground waters, and other natural resources will be protected. Such approval must be given in writing prior to the beginning of any abandonment procedures.

n. Within five days after the completion of the abandonment of any well or injection well, the owner or operator of the abandoned well or injection well shall report in writing to the Division on all iyork done with respect to the abandonment.

RULE 7 - MAINTENANCE

7-1 General: All well heads, separators, pumps, muffiers, manifolds, valves, pipelines, and other equipment used for the production of geothermal resources shall be maintained in good condition in order to prevent loss of or damage to life, health, property, and natural resources.

7-2 Corrosion: All surface well head equipment and pipelines and subsurface casing and tubing will be subject to periodic corrosion surveillance in order to safeguard health, life, property, and natural resources.

7-3 Tests: The Division may require such tests or remedial work as in its judgment are necessary to prevent damage to life, health, property, and natural resources, to protect geotinermal reservoirs 
fron damage or to provent the infiltration oi dacrimentai sub siances into underground or surface vater sultiole for irrigation or other beneficial uses to the best interest of the neighboring property owners and the public. Such tests may include, but are not limited to, casing tests, cementing tasts, and equipment tests.

RULE 8 - TEMPERATURE GRADIENT YELLS

8-1 General:

Wells may be drilled upon approval of the State Engineer for measurement of subsurface temperatures and conductive heat flow.

8-2 Information:

Request for a temperature gradient well program shall include the following information:

a. Well number

b. Well location, elevation and expected depth.

c. Geologic interpretation of area under investigation, including any known or inferred temperature data.

d. Proposed drilling program, including method and casing schedule.

e. Proposed method of abandonment.

f. The State Engineer may require other data and impose such restrictions or supervision by the Division as his studies may indicate.

\section{8-3 Conditions:}

The following general conditions shall apply to temperature gradient wells:

a. The deptin of the hole shall not exceed 500 feet unless otherwise authorized by the State Engineer.

b. The wells ara to be cased and sealed against the water in the forinations to be drilled.

c. Return rud or air temperatures shall be monitored at, at leasi 30) foot intervals and should the temperatura reach $125^{\circ} \mathrm{F}$. the drilling shall cease and the casing installed or the hole abandoned. Plastic casing may ba 
used at tamperduras under i250 F.; otherwisa, son? casing sinali be used.

d. Upon completion of the testing program, the casings are to be capped, or the casings are to be pulledi and tile holes cenanted from boicon to top.

e. The driller must be bonded and have a current we17 driller's permit from the State Engineer. Before starting, he must give this Division notice of the day he will begin drilling.

f. Temperature data and logs of each hole surveyed are to be subinitted to the State Engineer. These will be held in confidential status until released by the owner.

g. The driller shall exercise due caution in all drilling operations to prevent blowouts, explosions or fires.

RULE 9 - ENVIRONNENT

9-1 General:

The owner shall conduct exploration and development operations in a manner that provides maximum protection of the environment; rehabilitate disturbed lands; take all necessary precautions to protect the public health and safety; and conduct operations in accordance with the spirit and objectives of all applicable environmental legislation, executive orders and regulations.

Adverse environmental impacts from geothermal-related activity shall be prevented or mitigated through enforcement of applicable Federal, State, and local standards, and the application of existing technology. Inability to meet these environmental standards or continued violation of environmental standards due to operations of the lessee, after notification, may be construed as grounds for the State Engineer to order a suspension of operations.

RULE 10 - HEARINGS, APPEALS, PENALTIES

10-1 Hearings - Any interested person may petition the State Enginear for a hearing regarding these provisions. Hearings wilt ba held and conducied in accordance with Saction 73-3, Utah Code finnotated, 1953 and the Rules of Procedure for Hearings before the Division of Water Rights.

10-2 Appeal - Any person aggrieved by a decision of the Staic Engineer may, within sixiy (60) days arter notice thereof, bring a civil action in the district court for a plenary review thereos in accordance viti Sections 73-3-14 aild 73-3-15, ltan Code Annotated, 1953, as amendad. 
10-3 Penalios - Any wiliful violatim of or failure to cempiy with any provision of these regulations shiti be a misceneznor and each day that the violation contimes srall constitute a saparate offense. 